Article

\title{
Surface Interactions and Mechanisms Study on the Removal of Iodide from Water by Use of Natural Zeolite-Based Silver Nanocomposites
}

\author{
Vassilis J. Inglezakis ${ }^{1,2, *(\mathbb{D})}$, Aliya Satayeva ${ }^{1,2}$, Almira Yagofarova ${ }^{1,2}$, Zhandos Tauanov ${ }^{3}{ }^{\mathbb{D}}$, \\ Kulyash Meiramkulova ${ }^{4}\left(\mathbb{D}\right.$, Judit Farrando-Pérez ${ }^{5}$ and Joseph C. Bear ${ }^{6}$ \\ 1 Department of Chemical \& Materials Engineering, School of Engineering and Digital Sciences, \\ Nazarbayev University, Nur Sultan 010000, Kazakhstan; aliya.satayeva@nu.edu.kz (A.S.); \\ almira.yagofarova@nu.edu.kz (A.Y.) \\ 2 Environment \& Resource Efficiency Cluster (EREC), Nazarbayev University, Nur Sultan 010000, Kazakhstan \\ 3 Faculty of Chemistry and Chemical Technology, al-Farabi Kazakh National University, Almaty 050040, \\ Kazakhstan; zhtauanov@nu.edu.kz \\ 4 Department of Environmental Engineering \& Management, L.N.Gumilyov Eurasian National University, \\ Nur Sultan 010000, Kazakhstan; kuleke@gmail.com \\ 5 Laboratorio de Materiales Avanzados, Departamento de Química Inorgánica-Instituto Universitario de \\ Materiales, Universidad de Alicante, 03690 Alicante, Spain; juditfarrando95@gmail.com \\ 6 School of Life Science, Pharmacy \& Chemistry, Kingston University, Penrhyn Road, \\ Kingston upon Thames KT1 2EE, UK; J.Bear@kingston.ac.uk \\ * Correspondence: vasileios.inglezakis@nu.edu.kz
}

Received: 3 April 2020; Accepted: 15 May 2020; Published: 12 June 2020

\begin{abstract}
In this work a natural zeolite was modified with silver following two different methods to derive $\mathrm{Ag}_{2} \mathrm{O}$ and $\mathrm{Ag}^{0}$ nanocomposites. The materials were fully characterized and the results showed that both materials were decorated with nanoparticles of size of $5-25 \mathrm{~nm}$. The natural and modified zeolites were used for the removal of iodide from aqueous solutions of initial concentration of 30-1400 ppm. Natural zeolite showed no affinity for iodide while silver forms were very efficient reaching a capacity of up to $132 \mathrm{mg} / \mathrm{g}$. Post-adsorption characterizations showed that AgI was formed on the surface of the modified zeolites and the amount of iodide removed was higher than expected based on the silver content. A combination of experimental data and characterizations indicate that the excess iodide is most probably related to negatively charged AgI colloids and Ag-I complexes forming in the solution as well as on the surface of the modified zeolites.
\end{abstract}

Keywords: natural zeolite; nanocomposites; silver nanoparticles; silver oxide; iodide removal

\section{Introduction}

The contamination of water resources with toxic organic and inorganic pollutants is a serious global issue. The industries that predominantly pollute the water environment include chemicals production, metal processing, textile industry and paper and pulp industry. Concerning iodide, the major source of pollution comes from nuclear power plants [1-3]. The produced radioactive wastes, such as isotopes of iodide $\left({ }^{129} \mathrm{I}\right.$ and $\left.{ }^{131} \mathrm{I}\right)$, are typically used for the fission of uranium $[1,4,5]$. Despite the robust safety level in large-scale plants there are cases in the history when processes malfuncted leading to nuclear accidents. Among them is the most recent Fukushima disaster, happened in Japan in 2011, resulted in enormous discharge of $1.5 \times 10^{17} \mathrm{~Bq}$ radioactive isotope of iodine [4,5]. Another disaster happened in Chernobyl nuclear station in 1986 in Ukraine, resulted in the discharge of $1.76 \times 10^{18} \mathrm{~Bq}$ of radioactive iodine [4,5]. The adverse effects caused by radioactive discharges 
include severe health problems, especially following inhalation and ingestion. Such poisoning can potentially damage the kidney, liver and other human organs and may progress to thyroid cancer [6]. Furthermore, they can result in long-term issues since the radioactive elements possess long half-life time and bioaccumulation $[1,7,8]$. Besides radioactive iodide, another source of contamination comes from the tablets used for the purification of water, which contain iodine [9-11]. Dissolved iodine in natural water can exist in several forms such iodide $\left(\mathrm{I}^{-}\right)$, iodate $\left(\mathrm{IO}_{3}{ }^{-}\right)$, hypoiodous acid (HOI), and organic iodide while in tap water and in the presence of chlorine iodide can be oxidized to iodate [12].

As pollution affects all ecosystems various remediation approaches have been employed depending on the form iodine in the environment. Among most frequently and successfully applied methods for the removal of iodide from water, are the ion exchange and membrane separation [5,13]. These methods however are relatively expensive and, in particular during ion exchange, other ions are released into the solution. An effective and relatively simple method is adsorption using various porous materials, which are typically of low cost and can be easily modified for targeted iodide removal [5,14-17]. Such low cost adsorbents are the natural zeolites, which have been studied for iodide removal from water since decades. Utilization of natural zeolites as adsorbents has attracted considerable attention due to their structural and chemical properties. These materials are cheap, non-toxic, thermally and chemically stable and thus are excellent candidates for adsorption processes. Clinoptilolite is the most known and abundant natural zeolite extensively used in water and wastewater treatment [18-21]. Clinoptilolite has been widely used in adsorption of cations from water owing to its negatively charged structure and the presence of exchangeable cations $\left(\mathrm{Na}^{+}, \mathrm{K}^{+}, \mathrm{Ca}^{2+}\right.$ and $\left.\mathrm{Mg}^{2+}\right)$ but it has poor affinity towards anions [22]. Surfactants, organics, and noble metal doping can be used to enhance clinoptilolite affinity towards iodide [18,23-26]. Table 1 presents the studies using silver modified zeolites for the removal of iodide from water and gasses. In this case, the iodide is removed by the formation of insoluble AgI precipitate on the surface of the zeolites [3,5].

Table 1. Natural and synthetic silver modified zeolites applied for removal of iodide/ $\mathrm{CH}_{3} \mathrm{I}$ from water and gasses.

\begin{tabular}{|c|c|c|c|c|c|c|}
\hline Major Phase ${ }^{1}$ & Silver form & $\mathrm{I}^{-} / \mathbf{I}_{2},(\mathrm{ppm})$ & Initial $\mathrm{pH}$ & $\mathrm{m} / \mathrm{V}(\mathrm{g} / \mathrm{L})$ & Adsorption Capacity (mg/g) & Ref. \\
\hline \multicolumn{7}{|c|}{ Water phase $\left(\mathrm{I}^{-}\right)$} \\
\hline $\begin{array}{c}\text { Analcime/ } \\
\text { Sodalite (S) }\end{array}$ & $\mathrm{Ag}^{0}$ & 450 & 2.5 & 5 & 20.44 & [5] \\
\hline $\mathrm{Ag}-\mathrm{Z}(\mathrm{S})$ & $\mathrm{Ag}^{+}$ & 10 & 6.2 & 5 & 1.9 & [27] \\
\hline $\begin{array}{l}\text { Clinoptilolite/ } \\
\text { natrolite }\end{array}$ & $\mathrm{Ag}^{+}$ & $1270-12,700$ & $3-10$ & 5 & $146 / 52$ & [28] \\
\hline Clinoptilolite & $\mathrm{Ag}^{+}$ & $381-762$ & $6-7$ & - & 89 & [26] \\
\hline Clinoptilolite & $\mathrm{Ag}^{+}$ & $10^{-5} \mathrm{Ci} / 1^{2}$ & - & - & 178 & [29] \\
\hline \multicolumn{7}{|c|}{ Gas phase $\left(\mathbf{I}_{2}\right)$} \\
\hline $\operatorname{ZSM} 5(S)^{3}$ & $\mathrm{Ag}^{+}$ & 2000 & - & - & 0.05 & [30] \\
\hline Faujasite $^{3}$ & $\mathrm{Ag}^{0}$ & 1333 & - & - & 223 & [31] \\
\hline Modernite & $\mathrm{Ag}^{+} / \mathrm{Ag}^{0}$ & - & - & - & - & [32] \\
\hline Faujasite $^{3}$ & & & & & & \\
\hline Modenite $^{3}$ & & & & & & \\
\hline Ferrierite $^{3}$ & & & & & & \\
\hline ZSM $5(S)^{3}$ & & & & & & \\
\hline $\begin{array}{l}\text { BETA zeolite } \\
(\mathrm{S})^{3}\end{array}$ & $\mathrm{Ag}^{+}$ & 1333 & - & - & $46-267$ & [23] \\
\hline
\end{tabular}

As shown in Table 1, there are several studies on the use of natural and synthetic zeolites for iodide removal from water, especially zeolites modified with different silver forms $\left(\mathrm{Ag}^{0} \mathrm{or}^{\mathrm{Ag}} \mathrm{g}_{2} \mathrm{O}\right)$. All studies clearly showed the effectiveness of silver modification. Although the modification with noble metals might be considered costly, adding a small amount of silver forms into porous structures could substantially simplify the removal process by increasing the adsorption capacity, and sensitivity and reducing of resources required in comparison with other modified forms of zeolites. 
This study is a continuation of our previous research where we used fly ash-derived synthetic zeolites and cryogels doped with $\mathrm{Ag}^{0}$ for the removal of iodide [5,33]. Herein, natural clinoptilolite was modified with silver to produce two different nanocomposites containing metallic silver nanoparticles $\left(\mathrm{Ag}^{0}\right)$ and silver oxide nanoparticles $\left(\mathrm{Ag}_{2} \mathrm{O}\right)$. Adsorption equilibrium and kinetics are presented and a detailed study of the effect of silver forms on the iodide removal along with potential mechanisms is conducted. The conclusions are supported by advanced characterization methods. To the best of our knowledge there are no comprehensive studies on different silver-modified natural zeolites for iodide removal from water and on the mechanisms involved.

\section{Materials \& Methods}

\subsection{Materials and Modification}

The chemical reagents $\mathrm{NaCl}(\geq 99.0 \%), \mathrm{KI}(\geq 99.0 \%), \mathrm{AgNO}_{3}(>99.9 \%)$, and $\mathrm{NaBH}_{4}(99 \%)$ were purchased from Sigma-Aldrich (St. Louis, MO, USA). Ultrapure (UP) water with resistivity of 18.3 $\mathrm{M} \Omega \cdot \mathrm{cm}$ was obtained by Millipore filtration (Merck, MA, US). The natural zeolite of content of $80 \%$ clinoptilolite was obtained from the company "Transcarpathian zeolitic factory" (Khust district, Ukraine) and is referred as NZU (Natural Zeolite Ukraine) in the rest of paper. Sodium chlorite $(\mathrm{NaCl}, 99.5 \%)$, sodium borohydride $\left(\mathrm{NaBH}_{4}, 99.5 \%\right)$ and silver nitrate $\left(\mathrm{AgNO}_{3}, 99.8 \%\right)$ used for the nanocomposites synthesis were purchased from Sigma-Aldrich (St. Louis, MO, USA). Potassium iodide (KI, 99.8\%) used for the adsorption experiments was purchased from Fischer-Scientific (Hampton, NH, U).

\section{Natural Zeolite Pre-Treatment and Modification}

The natural zeolite sample was sieved on the vibrating sieve AS200 (Retsch, GmbH) and the particle size of 0.8-1.4 mm was used for further experiments. The zeolite was thoroughly washed with UP water and dried at $150{ }^{\circ} \mathrm{C}$ for $24 \mathrm{~h}(\mathrm{NZU})$. The pretreatment of zeolite was performed as follows: $100 \mathrm{~g}$ of $\mathrm{NZU}$ were added to $1 \mathrm{M} \mathrm{NaCl}$ at $60{ }^{\circ} \mathrm{C}$ and incubated for 7 days with daily replacement of the $\mathrm{NaCl}$ solution. Then the material was washed with UP water for the removal of excess of $\mathrm{NaCl}$ and the sodium form of the zeolite (NZU-Na) was dried at $60{ }^{\circ} \mathrm{C}$, and stored in a desiccator [34].

Two synthesis methods were followed. The synthesis of the $\mathrm{Ag}_{2} \mathrm{O} @ \mathrm{NZU}$ nanocomposite was performed following the method of Bo et al. [35]. First, $10 \mathrm{~g}$ of NZU-Na were added to $666 \mathrm{~mL}$ of $0.1 \mathrm{M}$ $\mathrm{AgNO}_{3}$ solution for $48 \mathrm{~h}$ in dark conditions. Then the samples were washed with UP water and dried for $24 \mathrm{~h}$ at $60^{\circ} \mathrm{C}$. For the $\mathrm{Ag}^{0} @ \mathrm{NZU}$ nanocomposite synthesis a method based on Lihareva et al. [34] and Tauanov et al. [36,37] was used. First, NZU-Na was converted to $\mathrm{Ag}^{+}$form by ion exchange by adding $100 \mathrm{~g}$ of zeolite to $250 \mathrm{~mL}$ of $0.04 \mathrm{M} \mathrm{AgNO}_{3}$ solution in dark conditions for $24 \mathrm{~h}$. Then, $13.5 \mathrm{~g}$ of the obtained $\mathrm{Ag}^{+}$form was added in $135 \mathrm{~mL}$ of $50 \mathrm{mM} \mathrm{AgNO}$ solution for $48 \mathrm{~h}$ in dark conditions. Finally, the reduction was done by immersing the zeolite in a $0.25 \mathrm{M}$ sodium borohydride solution until full coverage of the material for $1 \mathrm{~h}$ in cold conditions by using ice [38]. Following reduction the solution was filtered and the zeolite was dried in a bench oven at $90{ }^{\circ} \mathrm{C}$ for $8 \mathrm{~h}$. Although several methods $[9,39,40]$ of synthesizing silver nanoparticles (Ag NPs) are available, chemical reduction [39] is one of the most frequently applied methods to prepare them as colloidal dispersions in water or organic solvents. $\mathrm{AgNO}_{3}$ is the most commonly used precursor when preparing Ag NPs via the reduction route because of its good stability in polar solvents [9]. Sodium borohydride is one of several chemicals used as a reducing agent in the preparation of Ag NPs [11,41]. A layer of absorbed borohydride anions on the surface of the nanoparticles keeps the nanoparticles separated so to avoid agglomeration. Following drying, all zeolites were placed in closed containers and stored in a desiccator.

\subsection{Materials Characterization}

The chemical composition of the samples was studied by X-ray fluorescence (XRF) on an Axios Max (PANalytical, Malvern, UK). Measurements were done in vacuum, typically at $40-50 \mathrm{kV}$ and samples were prepared as pellets with $99.5 \%$ boric acid (Sigma-Aldrich, St. Louis, MO, USA) in a ratio of $1 / 3$. 
The matrix effects in the samples were adjusted by applying theoretical alpha factors and measured line overlap factors for the measured intensities. The standards that were used in the calibration procedures for analysis were the Omnian Monitor, Batch 08 from PANanalytical (Malvern, UK). X-ray photoelectron spectroscopy (XPS) spectra were recorded on a XPS K-ALPHA (Thermo Scientific Ltd., Waltham, MA, USA). All spectra were collected using an Al-K radiation (1486.6 eV), monochromatized by a twin crystal monochromator, yielding focused X-ray spot elliptical shaped with a major axis length of $400 \mu \mathrm{m}$ at $3 \mathrm{~mA} \times 12 \mathrm{kV}$. The alpha hemispherical analyser was operated at constant energy mode with survey scan pass energies of $200 \mathrm{eV}$ to measure the whole energy band and $50 \mathrm{eV}$ in a narrow scan to selectively measure the desired elements. Charge compensation was achieved with the system flood gun that provides low energy electrons and low energy argon ions from a single source. The $\mathrm{CH}_{\mathrm{x}}$ in carbon 1 s score level was used as reference binding energy $(284.8 \mathrm{eV})$. The powder samples were pressed and mounted on the sample holder and placed in the vacuum chamber. Before the pattern recording, the samples were maintained in the analysis chamber until a residual pressure of ca. $5 \times 10^{-7} \mathrm{Nm}^{-2}$. The peaks deconvolution was performed by a quantitative analysis calculating the integral of each peak, after subtracting the S-shaped background, and by fitting the experimental curve to a combination of Lorentzian (30\%) and Gaussian (70\%) models. The sample mineralogy was evaluated by using X-ray diffraction (XRD) spectrometry. Patterns were recorded using a Rigaku (SmartLab ${ }^{\circledR}$ X-ray, Tokyo, Japan) diffraction system with $\mathrm{Cu} \mathrm{K} \alpha$ radiation source $\left(\lambda=1.540056 \AA\right.$ ) at a scan rate of $0.02^{\circ} \theta \cdot \mathrm{s}^{-1}$ in the $2 \theta$ range of $5-90^{\circ}$. The data files were obtained by X'Pert Graphics \& Identify data collection software. The surface morphological characteristics of zeolites were studied by Scanning Electron Microscopy (SEM, Tokyo, Japan) using a JEOL 6380 LV scanning electron microscope, operating in LV mode, typically at $20-30 \mathrm{kV}$, equipped with a backscattered electron detector. Mapping analyses were carried out using a Si (Li) energy-dispersive x-ray spectrometer (INCA X-sight, Oxford Instruments, UK) connected to SEM. The nanoscale investigation was performed with the high-resolution JEM-2100 $\mathrm{LaB}_{6}$ transmission electron microscope (HRTEM, JEOL, Tokyo, Japan), operating at $200 \mathrm{kV}$. The porous structure was studied using low-temperature nitrogen adsorption measured on an Autosorb-1 (Quantachrome Instruments, Boynton Beach, FL, USA). The average pore size and total pore volume were calculated from the experimental data using the in-built software, while the pore size distribution was calculated using the BJH method.

\subsection{Adsorption Kinetics and Equilibrium}

The adsorption kinetics and equilibrium were done by bringing in contact $1 \mathrm{~g}$ of zeolite samples with $150 \mathrm{~mL}$ of iodide solutions without agitation and $\mathrm{pH}$ adjustment at room temperature. For kinetics experiments the concentrations of $200 \mathrm{ppm}$ and $800 \mathrm{ppm}$ were used and for the equilibrium experiments concentrations between 30 and $1400 \mathrm{ppm}$. Solution samples $(30-100 \mu \mathrm{L})$ were taken after specified time and diluted up to $3 \mathrm{~mL}$ by using UP water before measuring the residual iodide concentration by using a UV-Vis spectrophotometer (WTW PhotoLab 6600, Xylem, NY, US) at 225-227 nm wavelength. All adsorption experiments were conducted in static (batch) conditions. Samples were taken and analyzed until equilibrium was reached, i.e., until no changes in aqueous phase concentrations were observed. The total sampling volume was kept below $5 \%$ in all experiments. The amount of iodide adsorbed was calculated as follows:

$$
q_{e q}=\frac{C_{o}-C_{f}}{m} \times V
$$

where $q_{e q}$ is the iodide loading on the zeolite $(\mathrm{mg} / \mathrm{g}), C_{o}$ and $C_{f}$ are iodide concentrations $(\mathrm{mg} / \mathrm{L})$ in the initial and final solutions, respectively, $V$ the volume of solution (L), and $\mathrm{m}$ is the initial weight of the zeolite (g). To avoid confusion, throughout the paper, the term "loading" and symbol $q$ (mg/g) are used for the amount of species adsorbed per initial (before adsorption) weight of the solid phase and the term "content" and symbol $c_{t}(\mathrm{mg} / \mathrm{g})$ for the amount of species adsorbed per total weight of the solid phase (initial weight plus the weight of the adsorbed species). The former is typically used 
for kinetics and equilibrium studies while the later for XRF, EDS, and other compositional analyses. They are related as follows:

$$
c_{t}=\frac{q}{1+\left(\frac{q}{1000}\right)}
$$

The experiments were conducted in duplicate and the average values are presented. The average standard deviation of the solution concentration in kinetics experiments was 3.5\% and in equilibrium experiments $10 \%$. Control experiments showed that the iodide losses due to adsorption on the container walls are limited to an average of $2 \%$.

Leaching of $\mathrm{Ag}$ from the zeolites was studied by analyzing the solution phase after equilibrium was reached (typically 20-30 days). Two types of measurements were performed. In the first type the zeolite was separated with a screen of 100 microns opening in order to allow formed AgI colloids and precipitates to be collected in the filtrate. Sodium triosulfate $\left(\mathrm{Na}_{2} \mathrm{~S}_{2} \mathrm{O}_{3}\right)$ was added in the filtrate to dissolve the formed AgI. In the second type, only the supernatant solutions were analysed, with and without the addition of sodium triosulfate. The Ag concentration in the solutions was analyzed by using an Atomic Absorption Spectrometer (AAnalyst 400, Perkin Elmer, MA, US). Finally, a mercury equilibrium experiment was conducted by adding $1 \mathrm{~g}$ of zeolite in $150 \mathrm{~mL}$ of mercury solution of $200 \mathrm{ppm}$ concentration in static (batch) conditions at room temperature. To avoid mercury precipitation or the formation of hydrocomplexes, the initial $\mathrm{pH}$ was adjusted to 2 by using dilute $\mathrm{HNO}_{3}$. The mercury concentration was measured after $384 \mathrm{~h}$ by using the RA-915 M mercury analyzer (Lumex, Russia) which employs pyrolysis technique.

\section{Results and Discussion}

\subsection{Characterization of Modified Zeolites}

The mineralogical composition as determined by XRD is shown in Figure 1. NZU-Na shows the characteristic peaks of clinoptilolite at $9.8^{\circ}, 22.4^{\circ}$ and $30^{\circ}$. The peak at $26.6^{\circ}$ is attributed to quartz [42]. The peaks at $38.18^{\circ}, 44.3^{\circ}, 64.6^{\circ}$, and $77.5^{\circ}$ in the $\mathrm{Ag}^{0} @ \mathrm{NZU}$ sample are characteristic of metallic $\mathrm{Ag}^{0}$. The XRD pattern of $\mathrm{Ag}_{2} \mathrm{O} @ \mathrm{NZU}$ sample shows no new peaks of silver oxide, probably due to masking by clinoptilolite peaks in the same positions.

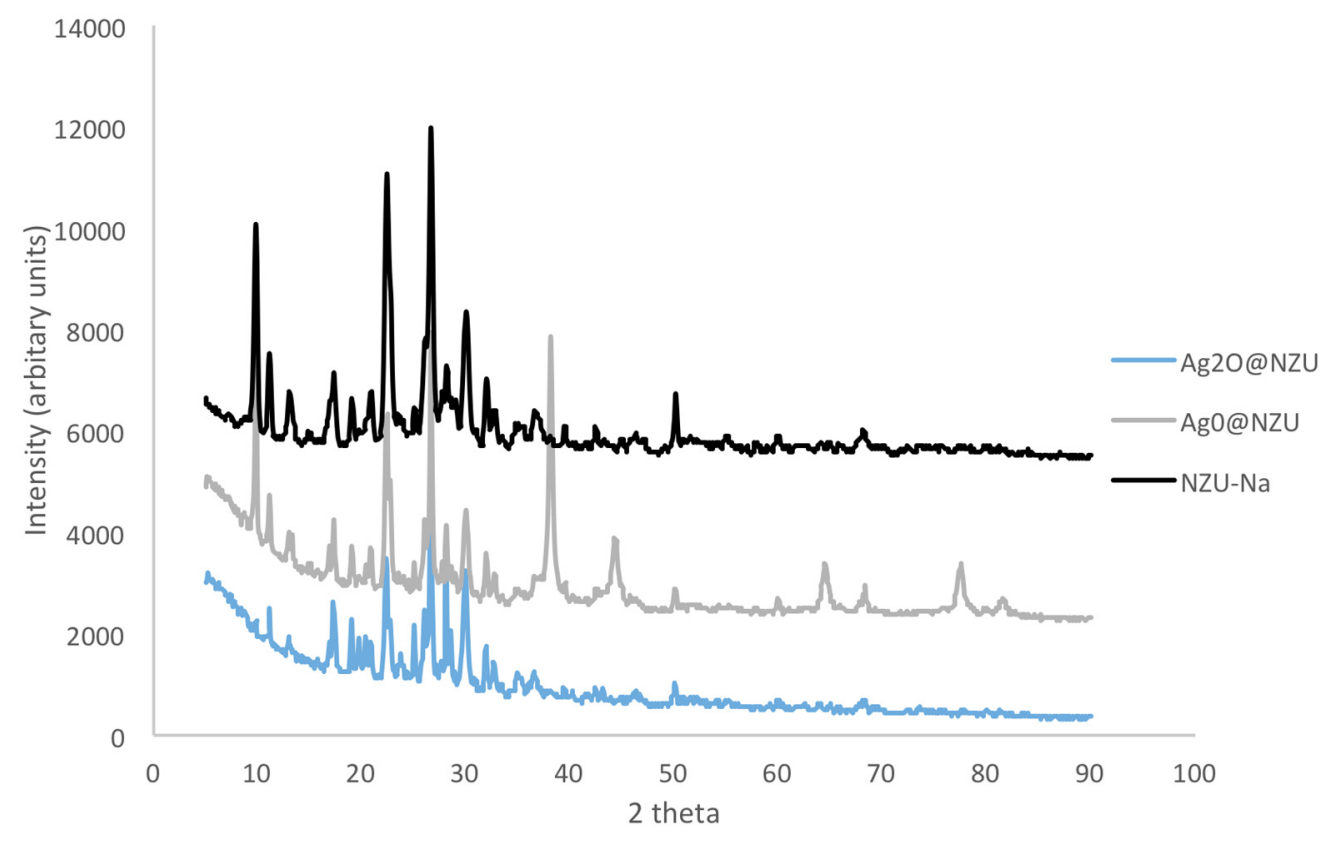

Figure 1. XRD patterns of $\mathrm{Ag}^{0} @ \mathrm{NZU}, \mathrm{Ag}_{2} \mathrm{O} @ \mathrm{NZU}$ and NZU-Na. 
The porosimetry results are presented in Table 2 and Figure 2. The hysteresis loop in the nitrogen adsorption-desorption isotherm for all samples is characteristic of mesoporous materials.

Table 2. BET/BJH analysis of zeolite samples.

\begin{tabular}{|c|c|c|c|}
\hline Sample & $\begin{array}{l}\text { Surface Area } \\
\left(\mathrm{BET}, \mathrm{m}^{2} / \mathrm{g}\right)\end{array}$ & $\begin{array}{l}\text { Total Pore Volume } \\
\qquad\left(\mathrm{BJH}, \mathrm{cm}^{3} / \mathrm{g}\right)\end{array}$ & $\begin{array}{l}\text { Average Pore Size } \\
\text { (BJH, nm) }\end{array}$ \\
\hline NZU & 12.6 & 0.027 & 5.82 \\
\hline NZU-Na & 12.5 & 0.032 & 2.98 \\
\hline $\mathrm{Ag}_{2} \mathrm{O} @ \mathrm{NZU}$ & 8.70 & 0.061 & 5.42 \\
\hline Ag 0 @NZU & 14.0 & 0.034 & 2.97 \\
\hline
\end{tabular}

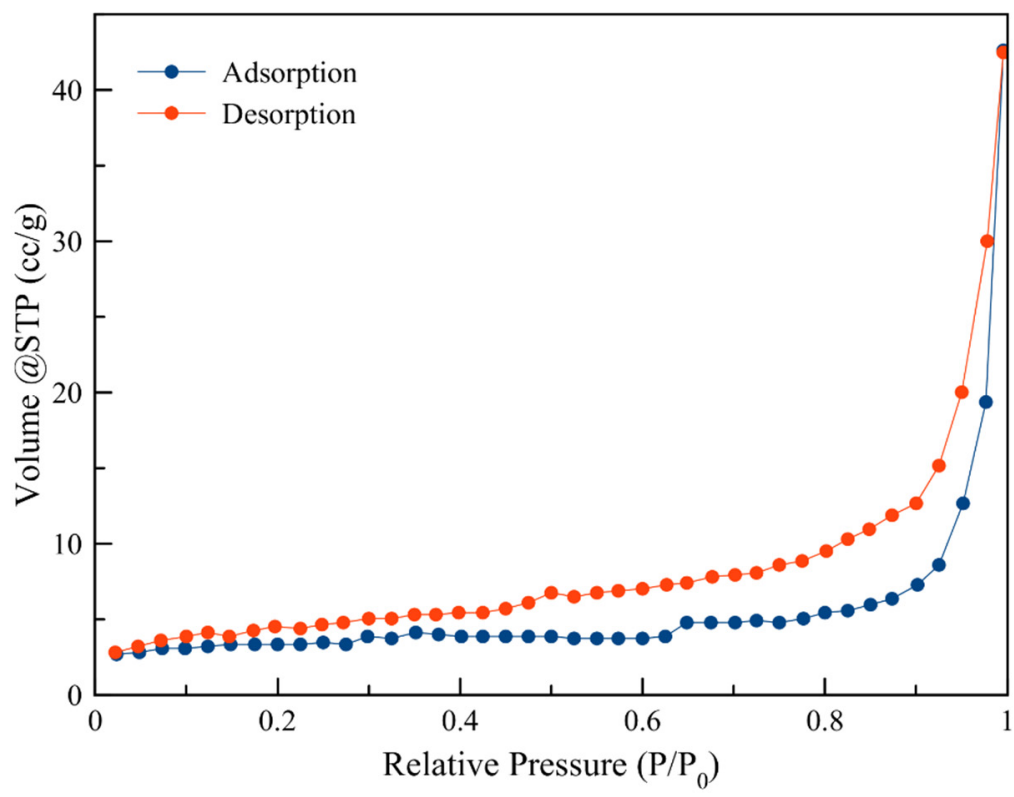

Figure 2. Adsorption-desorption isotherm for NZU.

The sorption-desorption and pore size distribution indicate that both samples possess a mesoporous structure. The clinoptilolite surface area and pore characteristics are not affected considerably by the $\mathrm{Na}$ and Ag modification procedures.

The chemical composition of modified zeolites clearly indicates the aluminosilicate nature of the material as shown in Table 3. The Si/Al molar ratio of the NZU sample is 5.32 as expected for clinoptilolite [42]. The NZU-Na sample is enriched in $\mathrm{Na}$ as expected after the modification with $\mathrm{NaCl}$, and according to the results, $\mathrm{Na}^{+}$it replaces $\mathrm{Ca}^{2+}$ from the zeolite structure. The $\mathrm{Ag}_{2} \mathrm{O} @ \mathrm{NZU}$ sample contains less $\mathrm{Na}, \mathrm{K}$ and $\mathrm{Ca}$ than NZU-Na due to the exchange with $\mathrm{Ag}^{+}$and the same is true for $\mathrm{Ag}^{0} @ \mathrm{NZU}$ with the exception of $\mathrm{Na}$, which is higher due to the use of sodium borohydride during reduction.

Table 3. XRF analysis results of zeolite samples $(\% w / w)$.

\begin{tabular}{ccccc}
\hline & $\mathbf{N Z U}$ & $\mathbf{N Z U - N a}$ & $\mathbf{A g}_{\mathbf{2}} \mathbf{O} @ \mathbf{N Z U}$ & $\mathbf{A g}^{\mathbf{0}} @ \mathbf{N Z U}$ \\
\hline $\mathrm{Na}_{2} \mathrm{O}$ & $1.13 \pm 0.01$ & 1.94 & $1.08 \pm 1.32$ & $2.42 \pm 1.34$ \\
$\mathrm{MgO}$ & $0.33 \pm 0.06$ & 0.27 & $0.41 \pm 0.18$ & $0.41 \pm 0.15$ \\
$\mathrm{Al}_{2} \mathrm{O}_{3}$ & $12.72 \pm 0.33$ & 12.70 & $11.67 \pm 0.37$ & $12.06 \pm 0.38$ \\
$\mathrm{SiO}_{2}$ & $76.55 \pm 1.10$ & 78.52 & $70.97 \pm 1.74$ & $72.84 \pm 2.08$ \\
$\mathrm{~K}_{2} \mathrm{O}$ & $3.22 \pm 0.33$ & 3.16 & $2.20 \pm 0.18$ & $2.45 \pm 0.26$ \\
$\mathrm{CaO}$ & $2.20 \pm 0.29$ & 0.82 & $0.44 \pm 0.06$ & $0.52 \pm 0.03$ \\
$\mathrm{Fe}_{2} \mathrm{O}_{3}$ & $1.60 \pm 0.05$ & 1.49 & $1.40 \pm 0.26$ & $1.41 \pm 0.20$ \\
$\mathrm{Ag}_{2} \mathrm{O}$ & - & - & $9.58 \pm 1.40$ & $5.92 \pm 3.55$ \\
\hline
\end{tabular}


The $\mathrm{Ag}^{0}$ nanoparticles formation, detected on XRD in all samples, was also detected by TEM imaging (Figure 3). It is obvious that in most cases the particle geometry corresponds to a well-defined spherical shape with sizes around of 5-25 nm with $\mathrm{Ag}^{0}$ nanoparticles generally being smaller than $\mathrm{Ag}_{2} \mathrm{O}$ nanoparticles. By using Scherrer equation with the three more intensive XRD peaks the estimated $\mathrm{Ag}^{0}$ nanoparticles size was $17.8 \mathrm{~nm}$, corroborating TEM results. The existence of nanoparticles in the $\mathrm{Ag}_{2} \mathrm{O} @ \mathrm{NZU}$ sample shows that the ion exchanged $\mathrm{Ag}^{+}$is either oxidized to $\mathrm{Ag}_{2} \mathrm{O}$ or it forms silver clusters. The photo-reduction of $\mathrm{Ag}^{+}$species and consequent formation of $\mathrm{Agm}^{\mathrm{n}+}$ clusters under light exposure during $\mathrm{Ag}^{+}$ion exchange has been reported for ZSM-5, NaX and NaY zeolites [43] and auto-reduction of $\mathrm{Ag}^{+}$to $\mathrm{Ag}_{\mathrm{m}}{ }^{\mathrm{n}}$ and $\mathrm{Ag}_{\mathrm{m}}{ }^{0}$ has been reported for faujasite [31].
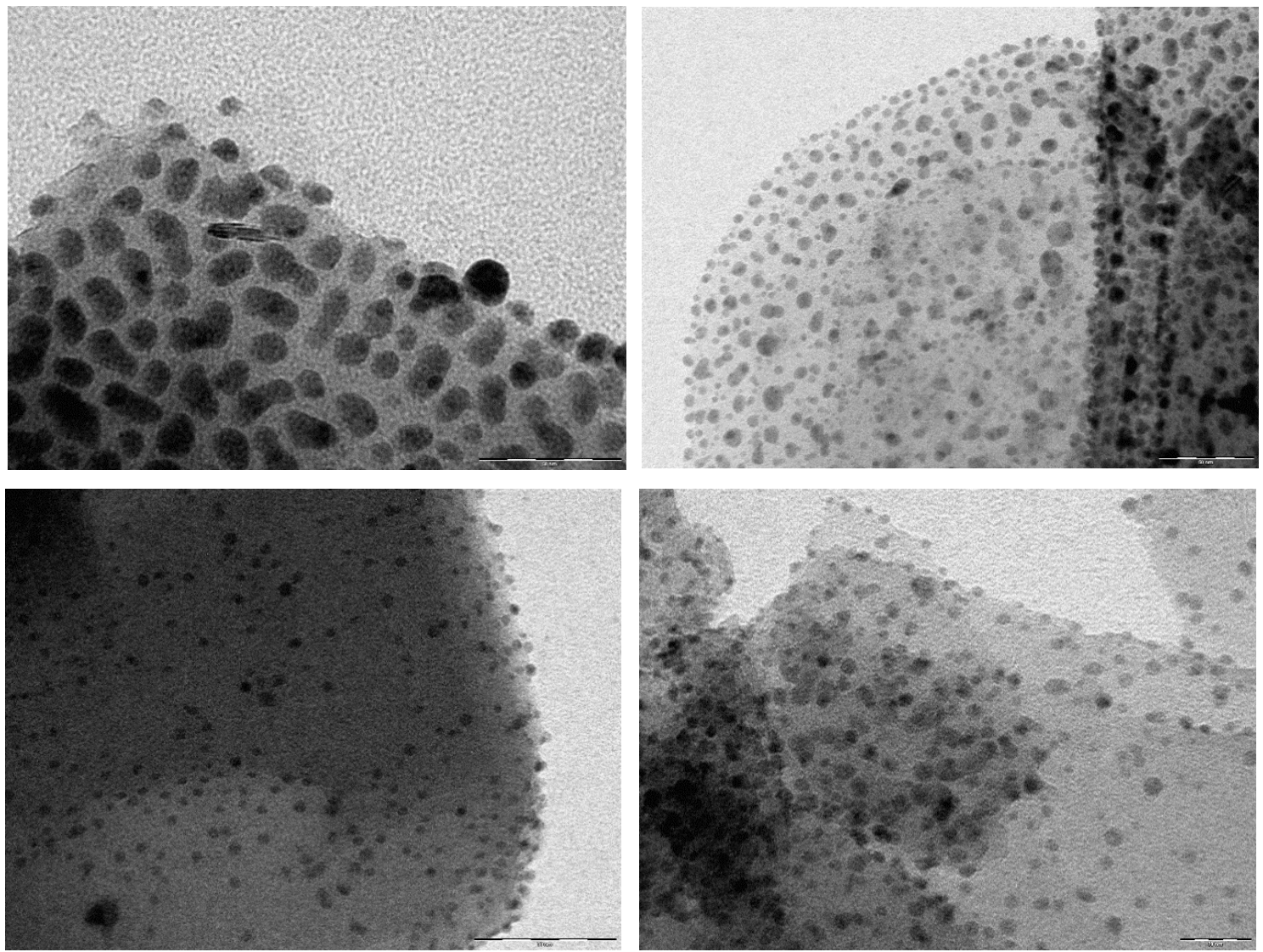

Figure 3. TEM images of $\mathrm{Ag}_{2} \mathrm{O} @ \mathrm{NZU}$ (upper left, scale $60 \mathrm{~nm}$ and upper right $50 \mathrm{~nm}$ ) and $\mathrm{Ag}^{0} @ \mathrm{NZU}$ (lower left, scale $60 \mathrm{~nm}$ and lower right, scale $20 \mathrm{~nm}$ ).

\subsection{The Adsorption Kinetics and Equilibrium}

The kinetic and equilibrium results are shown in Figures 4 and 5. As clinoptilolite is a cation exchanger iodide is not expected to be exchanged while adsorption is difficult owing to clinoptilolite's negative surface charge and its low to moderate surface area [42]. This is in agreement with the results as NZU showed less than $2 \%$ removal of iodide, in the range observed for the blank solutions. Faghihian et al. found that the adsorption of iodide on natural clinoptilolite is insignificant $(0.25 \mathrm{mg} / \mathrm{g})$ [28] although in a later study was found to be higher, between $4-10 \mathrm{mg} / \mathrm{g}$ [25]. Kubota et al. used a commercial zeolite which showed no affinity for iodide [44] and similar results were presented by Tauanov et al. for synthetic zeolites [5]. An exception is the work of Rehakova et al. who studied the modification of clinoptilolite of purity of $57.2 \%$ with iodide by using concentrated KI solutions in the concentration range of $0.1-1 \mathrm{~mol} / \mathrm{L}[45,46]$. The results showed that clinoptilolite can be loaded with an incredible amount of $4.21-13.45 \%$ w/w iodide. As discussed in Section 3.3, these results can be 
explained by the formation of crystalline $\mathrm{I}_{2}$ on the surface of the zeolites but given the low to moderate surface area of natural clinoptilolite the adsorption of such large amounts of $\mathrm{I}^{-}$and $\mathrm{I}_{2}$ is questionable.

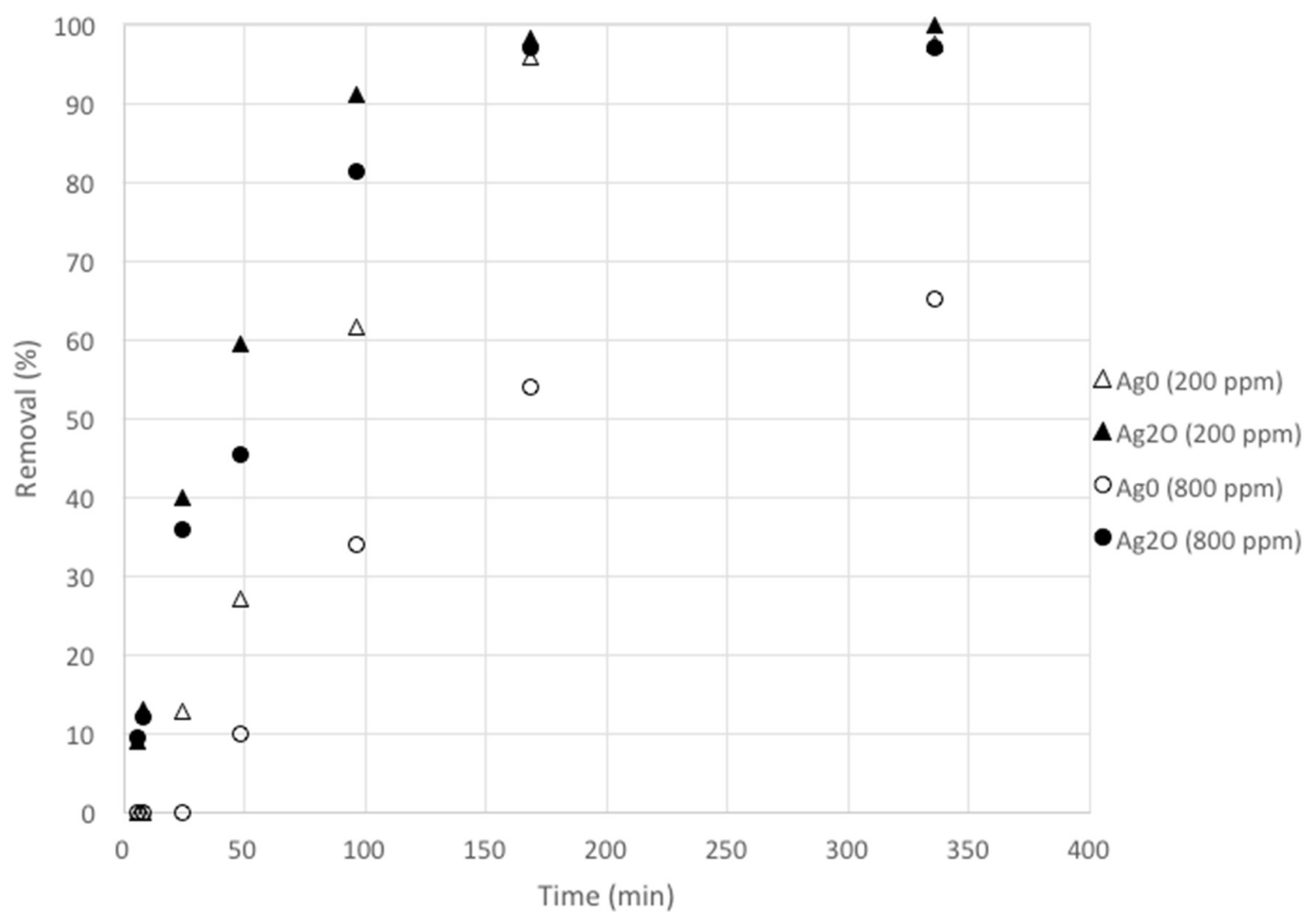

Figure 4. The adsorption kinetics of iodide on zeolite nanocomposites.

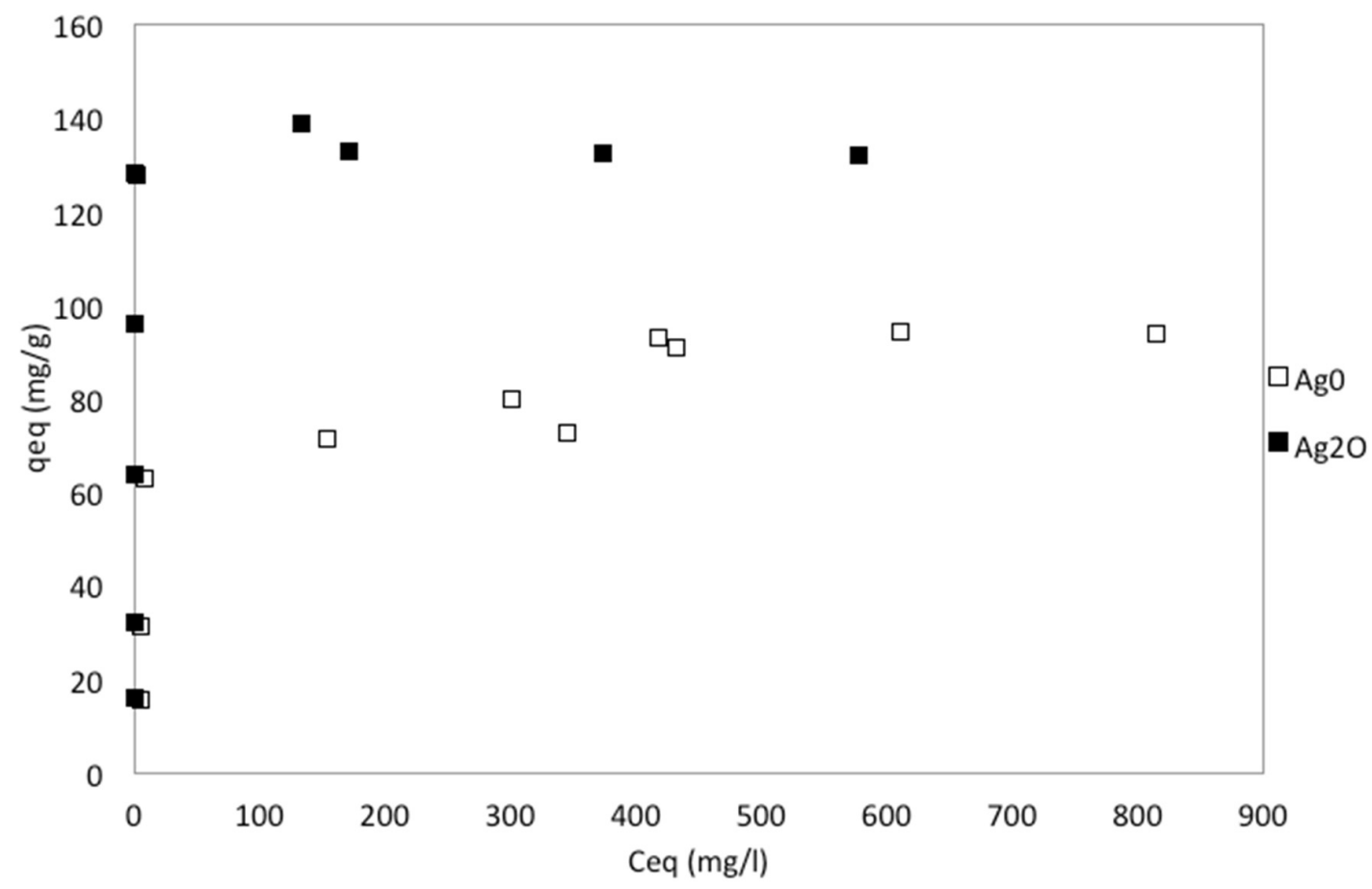

Figure 5. The adsorption equilibrium of iodide on zeolite nanocomposites.

Kinetics results showed that the removal of iodide is faster when using $\mathrm{Ag}_{2} \mathrm{O} @ \mathrm{NZU}$ and the lower the initial iodide concentration the higher the removal rate, as expected. Kinetics and equilibrium results 
clearly show that the rate of adsorption and the capacity is higher for $\mathrm{Ag}_{2} \mathrm{O} @ \mathrm{NZU}$. Also, equilibrium data indicate that the phenomenon is irreversible for $\mathrm{Ag}_{2} \mathrm{O} @ \mathrm{NZU}$ and reversible and Langmurian for $\mathrm{Ag}^{0} @ \mathrm{NZU}$. As formation of other iodide species can happen at low $\mathrm{pH}$ and oxidative conditions under certain conditions and may result in erroneous results is important to scan the solutions for identification of additional peaks. This was done during the experiments by scanning in the UV-Visible range from 190 to $400 \mathrm{~nm}$ and no peak other than the iodide peak was observed. $\mathrm{IO}_{3}{ }^{-}$shows no peaks and the intensity is gradually decreasing from $180 \mathrm{~nm}$ onwards, $\mathrm{I}_{2}$ shows a peak at $203 \mathrm{~nm}, \mathrm{I}^{-}$has a distinctive peak at $226 \mathrm{~nm}$, while $\mathrm{I}_{3}{ }^{-}$shows two peaks at 288 and $352 \mathrm{~nm}$ [7]. It should be noted that $\mathrm{I}_{3}{ }^{-}$is formed in the solution when $\mathrm{I}^{-}$and $\mathrm{I}_{2}$ co-exist [47].

The XRF analysis of the samples before iodide adsorption (Table 3) showed that the average Ag content is about $89 \mathrm{mg} / \mathrm{g}$ for $\mathrm{Ag}_{2} \mathrm{O} @ \mathrm{NZU}$ and $55 \mathrm{mg} / \mathrm{g}$ for $\mathrm{Ag}^{0} @ \mathrm{NZU}$. Based on these values and for Ag:I molar ratio of 1 the theoretical average amount of iodide that can be removed is about $105 \mathrm{mg} / \mathrm{g}$ for $\mathrm{Ag}_{2} \mathrm{O} @ \mathrm{NZU}$ and $65 \mathrm{mg} / \mathrm{g}$ for $\mathrm{Ag}^{0} @ \mathrm{NZU}$. These values are lower than the maximum measured in equilibrium experiments, about $132 \mathrm{mg} / \mathrm{g}$ for $\mathrm{Ag}_{2} \mathrm{O} @ \mathrm{NZU}$ and $94 \mathrm{mg} / \mathrm{g}$ for $\mathrm{Ag}^{0} @ \mathrm{NZU}$. Discrepancies between expected (based on Ag content) and observed (removal experiments) on iodide solid phase loading are not uncommon and not always explained [33,48-51]. As discussed in Section 3.3, the excess iodide removed can be explained by the formation of AgI colloids and Ag-I complexes in the solution and probably on the surface of the materials.

The XRF results after the adsorption of iodide from the $800 \mathrm{ppm}$ solution are shown in Table 4 and they confirm the presence of $\mathrm{I}^{-}$on the surface of the zeolites and that loading is higher in the $\mathrm{Ag}_{2} \mathrm{O} @ \mathrm{NZU}$ sample but the iodide amount is considerably lower than this measured in the equilibrium experiments. Several XRF iodide measurements were done in the framework of the present study and the iodide content was always underestimated. Taking into account the large number and the consistency of equilibrium experimental data, it is the authors' opinion that XRF results for iodide can only be used as rough approximations and, as discussed below, iodide losses during characterizations cannot be excluded. Also, there is a significant increase of the K content of the zeolites. This can be related to the considerable decrease of conductivity in all solutions beyond levels that can be explained by the removal of iodide alone (Figure 6). The measurements showed that the solutions conductivity after iodide removal is only $1-22 \%$ of the theoretical conductivity. The removal of $\mathrm{K}^{+}$ from the solution can be attributed to occlusion into the AgI precipitate or, as discussed in Section 3.3, to the adsorption on negatively charged AgI colloids or Ag-I complexes.

Table 4. XRF analysis results of zeolite samples after iodide adsorption (major elements only, $\% w / w)$.

\begin{tabular}{ccc}
\hline & $\mathbf{A g}_{2} \mathbf{O} @ \mathbf{N Z U}$ & $\mathbf{A g}^{\mathbf{0}} @ \mathbf{N Z U}$ \\
\hline $\mathrm{Na}_{2} \mathrm{O}$ & 0.4 & 1.37 \\
$\mathrm{MgO}$ & 0.69 & 0.63 \\
$\mathrm{Al}_{2} \mathrm{O}_{3}$ & 11.60 & 12.00 \\
$\mathrm{SiO}_{2}$ & 65.60 & 68.50 \\
$\mathrm{~K}_{2} \mathrm{O}$ & 6.94 & 7.18 \\
$\mathrm{CaO}$ & 0.35 & 0.41 \\
$\mathrm{Fe}_{2} \mathrm{O}_{3}$ & 1.29 & 1.21 \\
$\mathrm{Ag}_{2} \mathrm{O}$ & 8.73 & 5.78 \\
$\mathrm{I}$ & 3.97 & 2.27 \\
\hline
\end{tabular}

The porosimetry results do not show any significant changes besides the decrease of the total pore volume of the $\mathrm{Ag}_{2} \mathrm{O} @ \mathrm{NZU}$ and the increase of the average pore size of $\mathrm{Ag}^{0} @ \mathrm{NZU}$ (Table 5). These changes can be attributed to the blockage of the zeolite pores due to the formation of AgI precipitate, but the data are not clear enough to draw safe conclusions. 


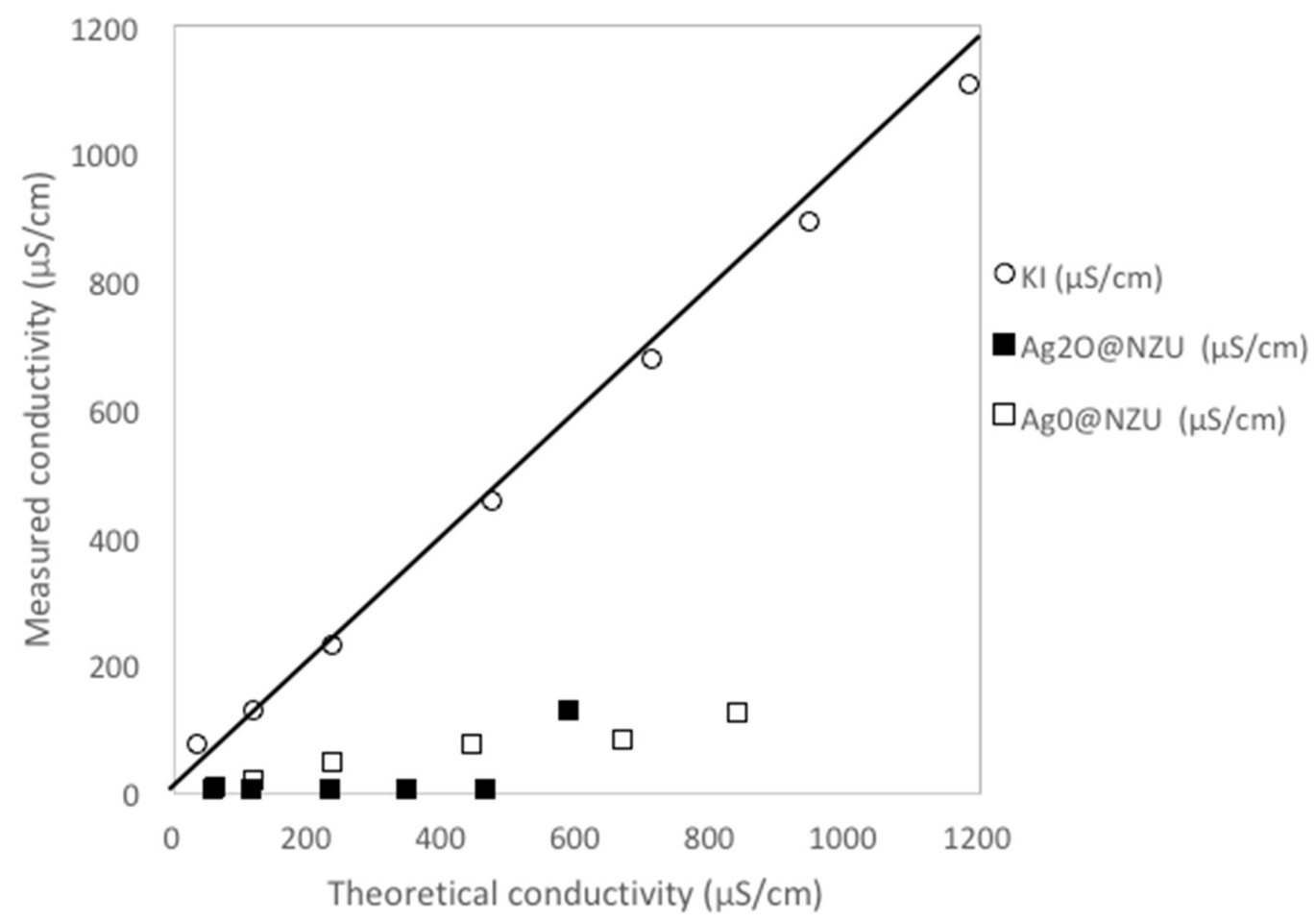

Figure 6. Solutions conductivity after $300 \mathrm{~h}$ for initial iodide concentrations of $30-1000 \mathrm{ppm}$. KI is the measured conductivity of the KI stock solutions. The limiting molar conductivities at $25{ }^{\circ} \mathrm{C}$ of $\mathrm{I}^{-}$ and $\mathrm{K}^{+}$of 7.68 and 7.352 in $\mathrm{mS} \mathrm{m} / \mathrm{mol}$, respectively were used for the estimation of the theoretical solutions conductivity. This conductivity was calculated assuming that all $\mathrm{K}^{+}$remains as free ion in the solution and no other ion besides $\mathrm{I}^{-}$is removed or released in the solution.

Table 5. BET analysis of zeolite samples after iodide adsorption.

\begin{tabular}{|c|c|c|c|}
\hline Sample & $\begin{array}{l}\text { Surface Area } \\
\left(B E T, \mathrm{~m}^{2} / \mathrm{g}\right)\end{array}$ & $\begin{array}{l}\text { Total Pore Volume } \\
\quad\left(\mathrm{BJH}, \mathrm{cm}^{3} / \mathrm{g}\right)\end{array}$ & $\begin{array}{c}\text { Average Pore Size } \\
\text { (BJH, nm) }\end{array}$ \\
\hline $\mathrm{Ag}_{2} \mathrm{O} @ \mathrm{NZU}$ & 11.9 & 0.035 & 3.73 \\
\hline Ag0@NZU & 10.5 & 0.028 & 9.02 \\
\hline
\end{tabular}

The surface morphology of modified zeolites after adsorption of iodide from the $1000 \mathrm{ppm}$ solution was studied using SEM analysis (Figure 7). SEM images clearly show that Ag and I are found on the same spots and at high magnification crystals of a precipitate are covering the surface of the materials, presumably AgI. In total four SEM/EDS elemental mapping measurements over areas from $1.5 \times 1.5 \mu \mathrm{m}$ to $150 \times 150 \mu \mathrm{m}$ for each sample were performed and the results showed that the Ag:I molar ratio is $1.22 \pm 0.03$ for the $\mathrm{Ag}_{2} \mathrm{O} @ \mathrm{NZU}$ sample and $1.32 \pm 0.20$ for the $\mathrm{Ag}^{0} @ \mathrm{NZU}$ sample (Figure 8). Based on the equilibrium results for this concentration the samples have reached saturation (Figure 5). This means that some Ag is not reacting, corroborating the XRD results, which show that some amount of $\mathrm{Ag}^{0}$ remained on the surface of the $\mathrm{Ag}^{0} @ \mathrm{NZU}$ sample (Figure 10). However, the major reason of lower than expected iodide content detected by SEM/EDS may be due to losses during characterization. For instance, AgI losses during XRD and SEM/EDS characterizations were observed in a study of methyl iodide adsorption on a silver ion-exchanged ZSM- 5 and they were attributed to detachment of the precipitate particles from the surface of the zeolite [30]. Also, AgI decomposes under light, high energy electron beams, as in TEM analysis and in any other environment where temperature is above $150{ }^{\circ} \mathrm{C}[23,52-54]$. If this happens, $\mathrm{I}_{2}$ is formed and evaporates according to the following reaction:

$$
\mathrm{AgI} \rightarrow \mathrm{Ag}^{0}+\mathrm{I}_{2}
$$



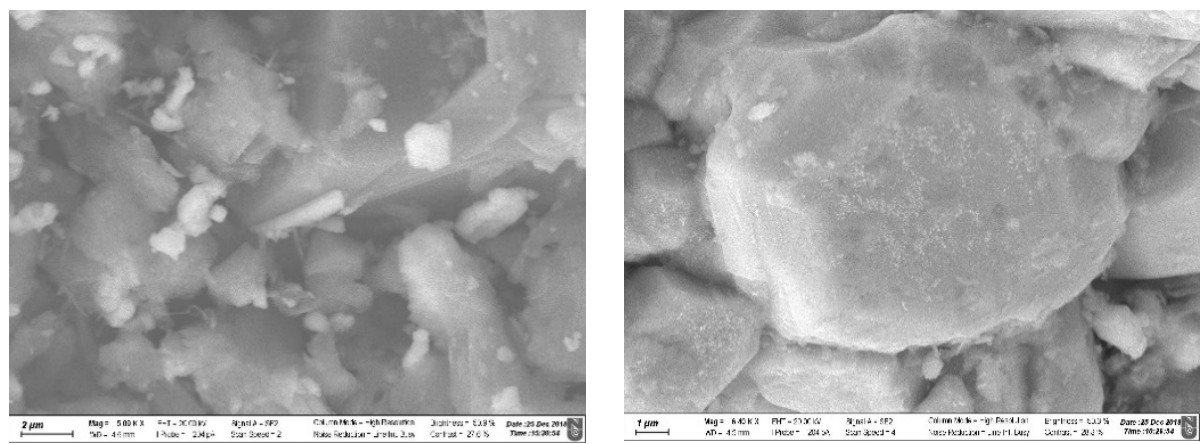

Figure 7. SEM images of $\mathrm{Ag}_{2} \mathrm{O} @ \mathrm{NZU}$ (left) and $\mathrm{Ag}^{0} @ \mathrm{NZU}$ (right) samples (scale 1-2 $\left.\mu \mathrm{m}\right)$.
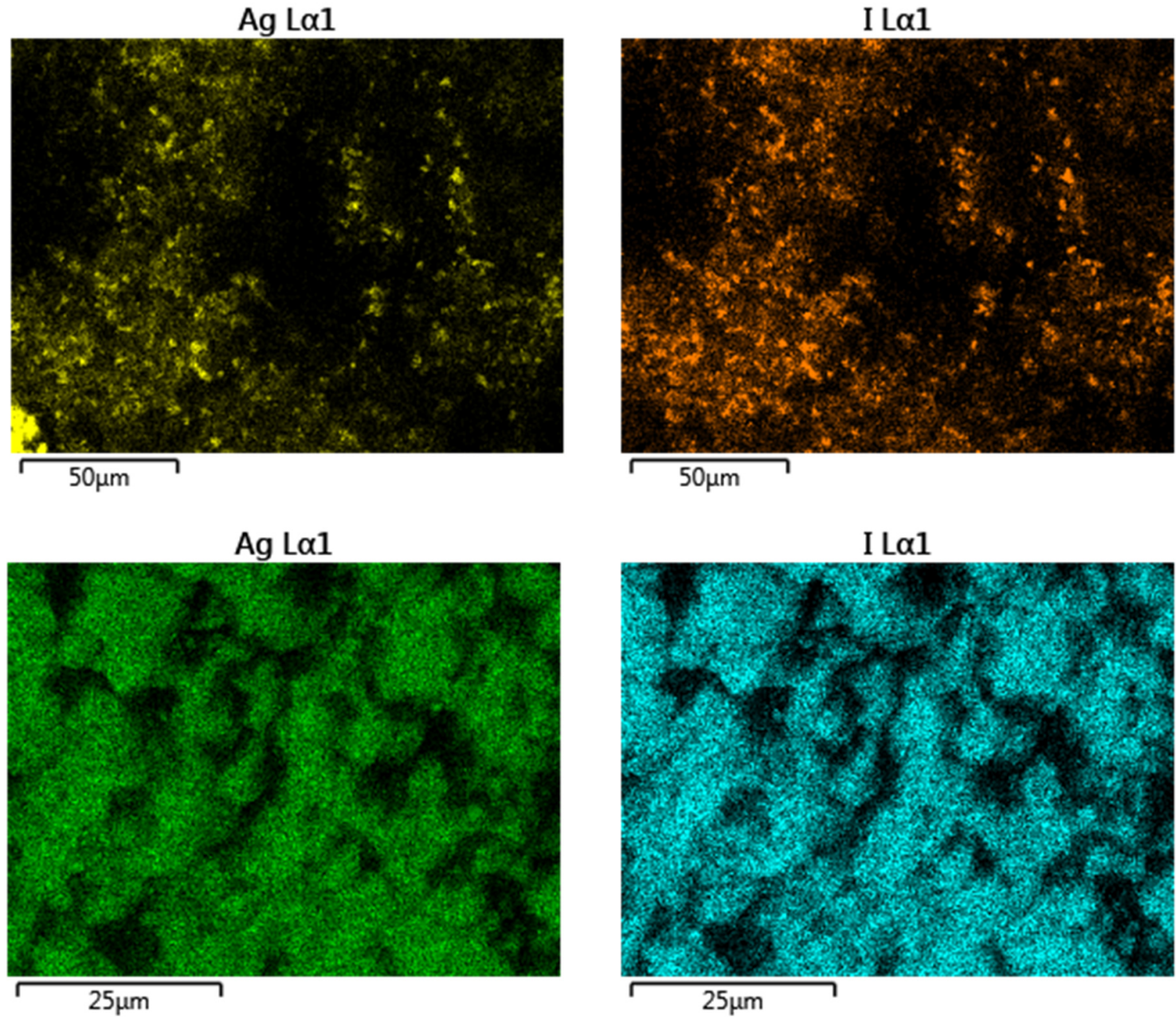

Figure 8. SEM/EDS mapping images of $\mathrm{Ag}_{2} \mathrm{O} @ \mathrm{NZU}$ (upper) and $\mathrm{Ag}^{0} @ \mathrm{NZU}$ (lower) samples.

TEM analysis performed on the samples after iodide adsorption from the 200 ppm solution showed less nanoparticles and dark areas as a result of the surface coverage with the precipitate (Figure 9). TEM/EDS analysis of individual Ag nanoparticles after the iodide adsorption showed very low iodide content, confirming the AgI decomposition under high-energy electron beams. 

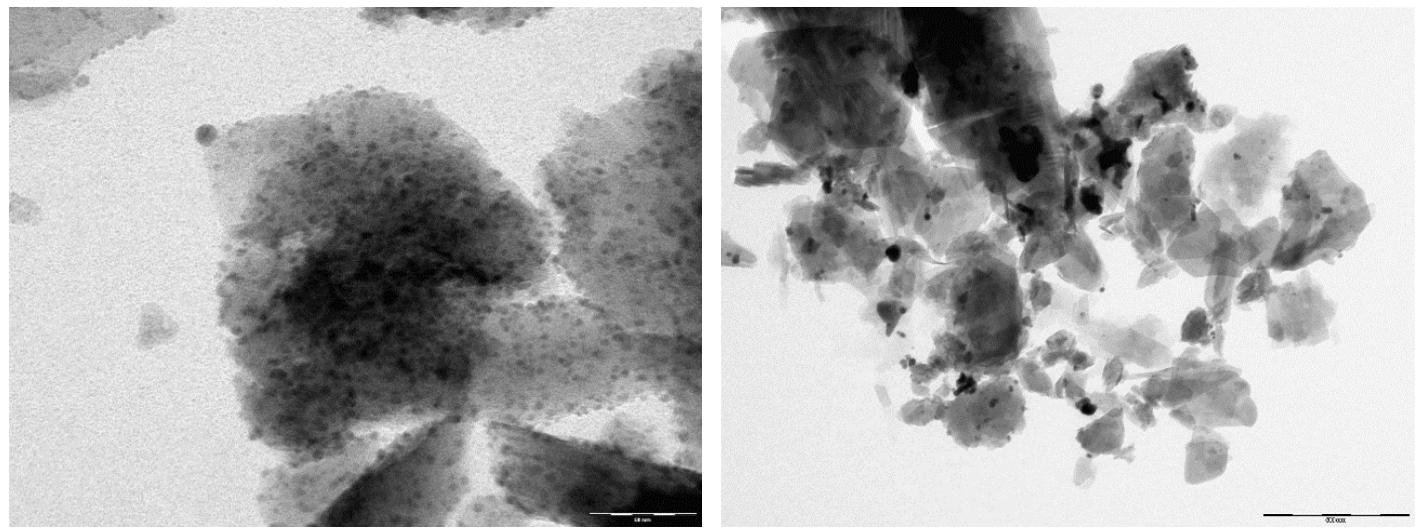

Figure 9. TEM images of $\mathrm{Ag}_{2} \mathrm{O} @ \mathrm{NZU}((\mathbf{l e f t})$, scale $50 \mathrm{~nm})$ and $\mathrm{Ag}^{0} @ \mathrm{NZU}$ ((right), scale $\left.500 \mathrm{~nm}\right)$ samples.

The formation of AgI precipitate on the surface of the material was not confirmed by XRD analysis (Figure 10). This can be explained by the masking of AgI peaks by zeolite peaks at $22.39^{\circ}, 23.68^{\circ}, 39.40^{\circ}$, $42.68^{\circ}$, and $46.4^{\circ}$. The only difference between the $\mathrm{Ag}_{2} \mathrm{O} @ \mathrm{NZU}$ and $\mathrm{Ag}^{0} @ \mathrm{NZU}$ samples is the $\mathrm{Ag}^{0}$ peak at $38.1^{\circ}$. Also, the other $\mathrm{Ag}^{0}$ peaks disappeared, a result of the oxidation by dissolved oxygen and the interaction with iodide.

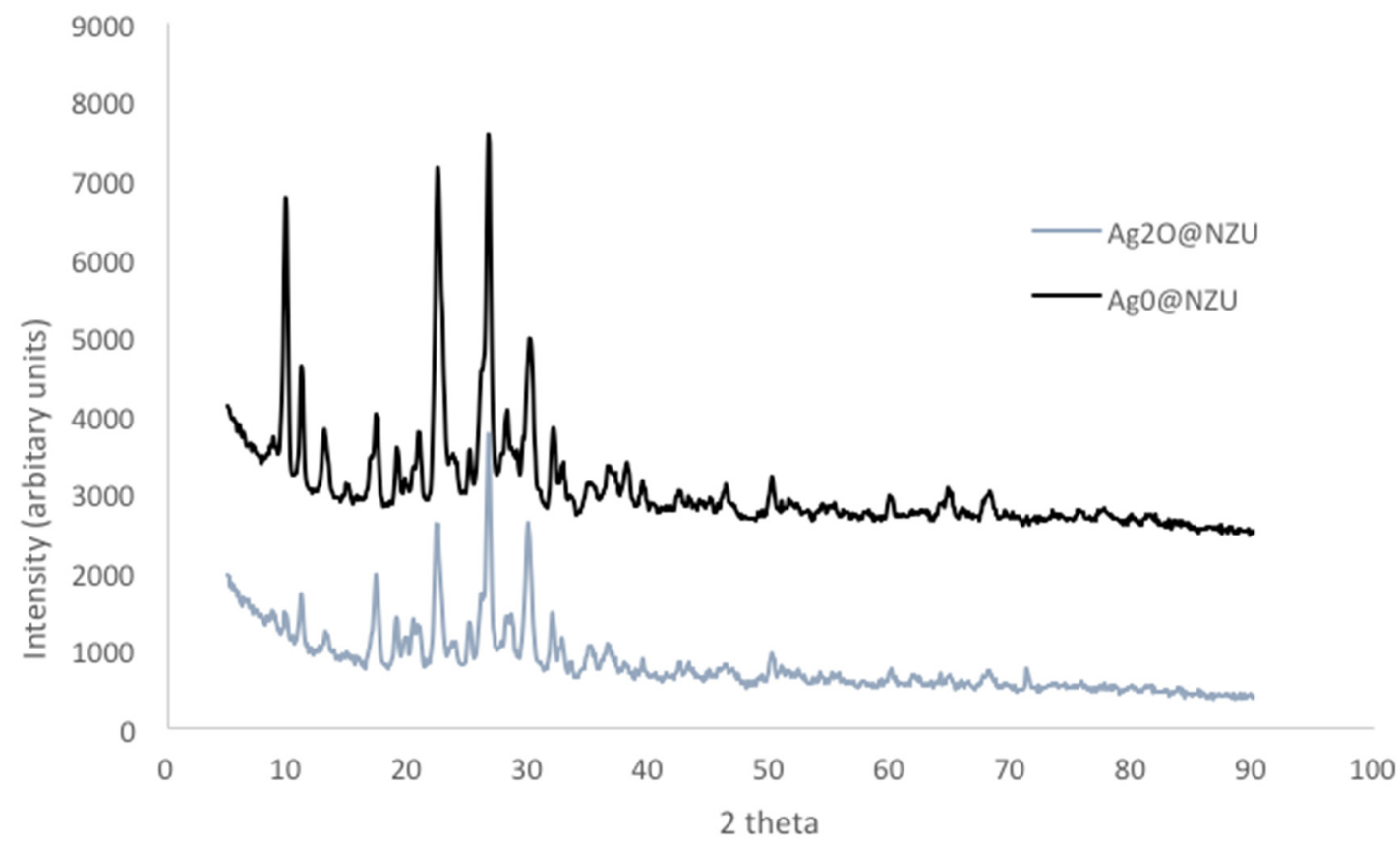

Figure 10. XRD pattern of modified zeolites after iodide adsorption.

A detailed discussion is dedicated to XPS analysis as is important for deriving the oxidation state of the silver and iodide on the zeolite surface. The results are presented in Figure 11 and Table 6. The expected the 1s peak of $\mathrm{Na}_{2} \mathrm{O}$ is at $1072.5 \mathrm{eV}$, close to this of the molecular sieves $\mathrm{A}, \mathrm{X}$, and $\mathrm{Y}$ which is in the range of 1071.5-1072.6 eV [55]. Two oxidation states were observed for silver before iodide adsorption and in combination to XRD and TEM results they most probably belong to $\mathrm{Ag}_{2} \mathrm{O}$ and $\mathrm{Ag}^{0}$. After the iodide adsorption one silver oxidation state is detected, presumably $\mathrm{Ag}^{+}$resulting from the formation of AgI. According to the NIST database, the $3 \mathrm{~d}_{5 / 2}$ peak of $\mathrm{Ag}^{0}$ is in the range of 367.9-368.3 eV and of $\mathrm{Ag}_{2} \mathrm{O}$ in the range of 367.7-368.4 eV [55]. After the adsorption of iodide one oxidation state of iodide is detected at $619.9-620.6 \mathrm{eV}$, which is either $\mathrm{I}^{-}$or $\mathrm{I}_{2}$. The expected $3 \mathrm{~d}_{5 / 2}$ peak of $\mathrm{I}^{-}$in AgI is in the range of $619-619.5 \mathrm{eV}$ and of $\mathrm{I}_{2}$ in the range of $619.9-620.8 \mathrm{eV}[55,56]$. However, $3 \mathrm{~d}_{5 / 2}$ peaks of iodide at $619.3-619.9$ and even as high as $623.5 \mathrm{eV}$ have also been reported [56-58]. 
The $3 \mathrm{~d}_{5 / 2}$ peaks of $\mathrm{Ag}^{0}$ in the $\mathrm{Ag}^{0} @ \mathrm{NZU}$ are only slightly shifted to higher value and are close to the reported values. The rest of $\mathrm{Ag}$ peaks and the $1 \mathrm{~s}$ peak of $\mathrm{Na}_{2} \mathrm{O}$ are shifted to higher values, especially those of the zeolites before iodide adsorption. Taking these shifts into account, the $3 \mathrm{~d}_{5 / 2}$ peaks in the range of 619.9-620.6 can be attributed to $\mathrm{I}^{-}$. In general, the higher oxidation states of iodine the higher the binding energy [58]. Thus, if iodide becomes more electropositive is possible to show a shift to higher binding energy. These shifts to higher binding energy can be explained by the effect of the zeolite matrix as discussed below.

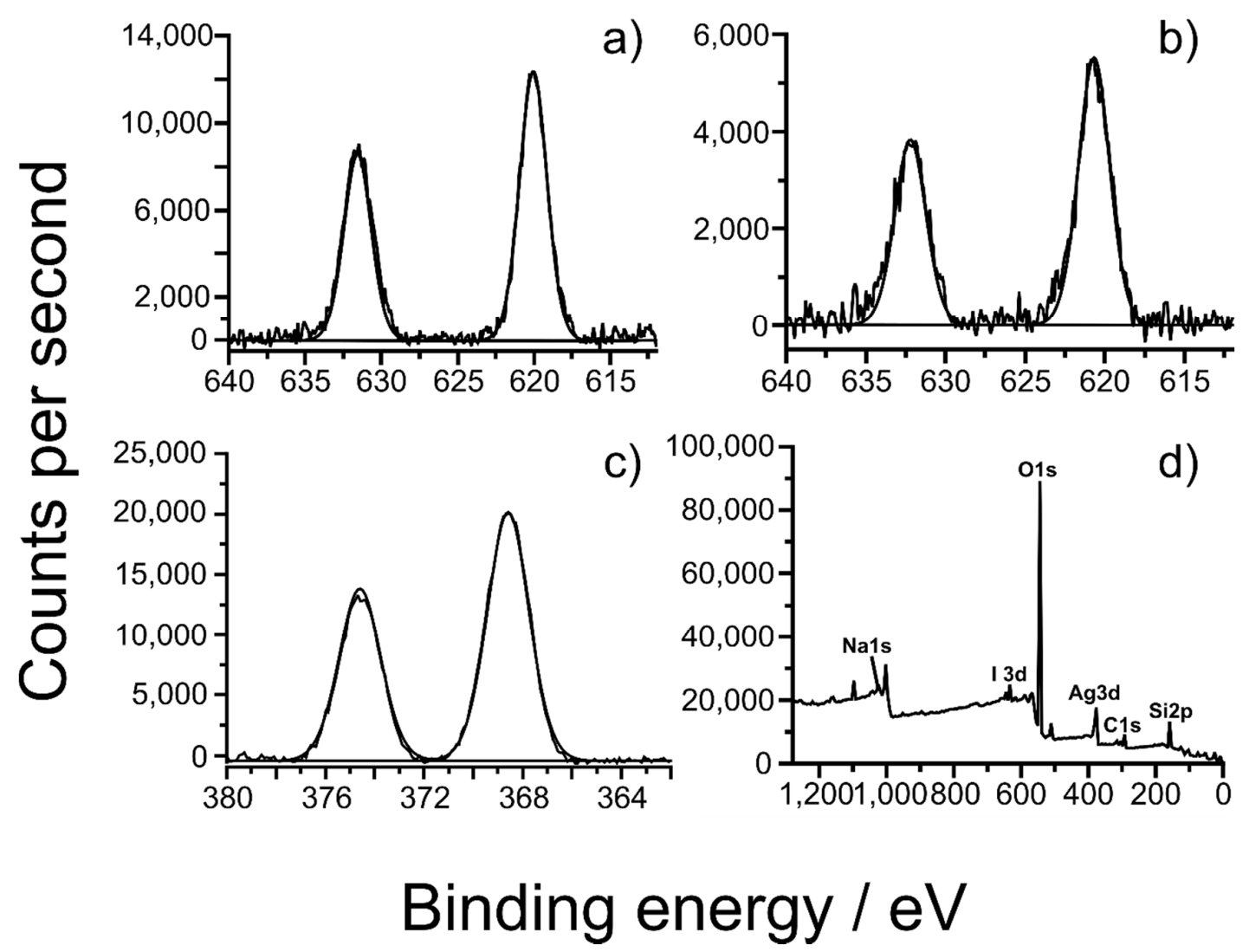

Figure 11. XPS results after interaction with iodide. Figures show: high resolution scans of (a) I3d of $\mathrm{Ag}^{0} @ \mathrm{NZU}$ at $200 \mathrm{ppm} \mathrm{I}^{-}$, (b) I3d of $\mathrm{Ag}_{2} \mathrm{O} @ \mathrm{NZU}$ at 800 ppm I ${ }^{-}$, (c) $\mathrm{Ag} 3 \mathrm{~d}$ of $\mathrm{Ag}^{0} @ \mathrm{NZU}$ at 800 ppm I and (d) $\mathrm{Ag}^{0} @ \mathrm{NZU}$ at $200 \mathrm{ppm} \mathrm{I}^{-}$survey.

Table 6. XPS binding energy results (eV).

\begin{tabular}{|c|c|c|c|c|c|c|}
\hline & $\mathrm{Ag}_{2} \mathrm{O}$ & $\mathbf{A g}^{0}$ & $\begin{array}{c}\mathrm{Ag}_{2} \mathrm{O} \\
\left(200 \mathrm{ppm} \mathrm{I}^{-}\right)\end{array}$ & $\begin{array}{c}\mathrm{Ag}^{0} \\
\left(200 \mathrm{ppm} \mathrm{I}^{-}\right)\end{array}$ & $\begin{array}{c}\mathrm{Ag}_{2} \mathrm{O} \\
\left(800 \mathrm{ppm} \mathrm{I}^{-}\right)\end{array}$ & $\begin{array}{c}\mathrm{Ag}^{0} \\
\left(800 \mathrm{ppm} \mathrm{I}^{-}\right)\end{array}$ \\
\hline C1s Scan A & 284.6 & 284.6 & 284.6 & 284.6 & 284.6 & 284.6 \\
\hline Ag3d $_{5 / 2}$ Env. A & 369.2 & 368.5 & 370.4 & 368.6 & 369.1 & 368.5 \\
\hline 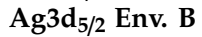 & 370.4 & 369.7 & - & - & - & - \\
\hline $\mathbf{I}^{3} \mathrm{~d}_{5 / 2}$ Scan A & - & - & 620.6 & 620.0 & 620.6 & 619.9 \\
\hline Na1s Scan A & 1073.2 & 1073.1 & 1072.7 & 1072.9 & 1072.7 & 1072.8 \\
\hline
\end{tabular}

As is well-known, besides chemical shifts, XPS peak positions are affected by the local electrostatic environment induced by the surface of the substrate and/or the surrounding polar groups $[59,60]$. Large differences in electronegativity between the elements of a solid are sometimes responsible for shifts in the binding energy and a very electronegative element shifts the binding energy of neighboring atoms to higher values [61]. These shifts are superimposed on the commonly observed chemical shifts and can easily be in the range of $1 \mathrm{eV}[62,63]$. It is noteworthy that zeolitic materials containing metal dopants are much studied using XPS in the literature, but consensus on how metal 
dopants/additives behave is elusive. XPS analysis of zeolites is particularly challenging due their poor electrical conductivity and surface inhomogeneity. As a result, the range of chemical shifts for most elements is small compared to the uncertainties in the determination of the values [64] and thus literature data can only be considered as trend indicators. For example, Gunter et al. studied chabazite and found pronounced shifts for the $\mathrm{Fe} 2 \mathrm{p}_{3 / 2}$ peak at $714.6 \mathrm{eV}$ compared to 709.9-711.6 eV for $\mathrm{Fe}_{2} \mathrm{O}_{3}$ and the $\mathrm{Cu} 2 \mathrm{p}_{3 / 2}$ peak at $936.7 \mathrm{eV}$ compared to $932.7-934.6 \mathrm{eV}$ for $\mathrm{CuO}[55,65]$. Ruiz-Serrano et al. studied clinoptilolite and the $\mathrm{Ca} 2 \mathrm{p}_{3 / 2}$ was shifted to $348.3 \mathrm{eV}$ compared to $346.1-347.3 \mathrm{eV}$ for $\mathrm{CaO}$ and the $\mathrm{Fe} 2 \mathrm{p}_{3 / 2}$ peak was shifted to $713.3 \mathrm{eV}[55,66]$. The authors concluded that the shift in the energy binding of elements in solids such as zeolites can be attributed to the chemical environment of the matrix and are correlated with the $\mathrm{Si} / \mathrm{Al}$ ratio. Chmielewska et al. studied nano-FeO $(\mathrm{OH})$ modified clinoptilolite and found a shift of $\mathrm{Fe} 2 \mathrm{p}_{3 / 2}$ at $713 \mathrm{eV}[55,67]$. This shift was attributed to the effect of $\mathrm{Al}$ atoms of the zeolite structure. Rehakova et al. studied iodide forms of clinoptilolite and identified $3 \mathrm{~d} 5 / 2$ peaks at $619.3 \mathrm{eV}$ and $621.1 \mathrm{eV}$ attributed to I- and I2, respectively [45]. Panayotova et al. studied a silver modified clinoptilolite and the $3 \mathrm{~d} 5 / 2 \mathrm{Ag} 0$ peak at $369.3 \mathrm{eV}$ [68]. The authors state that this shift to higher binding energy could be due to the small size of silver nanoparticles. Borko et al. studied clinoptilolite loaded with $\mathrm{Pd}$ and found that the presence of $\mathrm{PdO} 2$ is indicated by the $\mathrm{Pd}$ $3 \mathrm{~d} 5 / 2$ peak at $339 \mathrm{eV}$ binding energy compared to $337.9 \mathrm{eV}$ reported for PdO2 [55,69]. Zhai et al. found that the binding energy of the guest in the zeolite host-AgI composite materials, such as silver and iodine elements, shifted to higher energies [56]. For instance, the binding energy of $\mathrm{I}^{3} \mathrm{~d}_{5 / 2}$ level moved from $619.5 \mathrm{eV}$ for bulk silver iodide to $619.9 \mathrm{eV}$ for the NaZSM-5-AgI composite. An exception to the studies above is the shift to lower binding energy reported by We et al. [70] who studied a clinoptilolite/mordenite sample and after modification with $\mathrm{Na}^{+}$a new peak for $\mathrm{Na}$ 1s at a binding energy of $1060.1 \mathrm{eV}$ was identified.

Therefore, in our study, the $\mathrm{Ag} 3 \mathrm{~d}_{5 / 2}$ peak shifts to higher binding energy, is probably attributed to sample charging and the $\mathrm{Si}$ of the zeolite matrix. This is supported by a recent paper highlighting the inaccuracy of XPS calibration in charging samples, particularly those which are not electrically conductive such as zeolites [71]. The iodide high resolution scans are more eloquent that these of ssilver, indicating the strong possibility of the presence of $\mathrm{I}^{-}$with single environment and binding energies for the $\mathrm{I}_{3} \mathrm{~d}_{5 / 2}$ in the $619.9-620.6 \mathrm{eV}$ range, attributable to $\mathrm{I}^{-}$.

\subsection{Removal Mechanism and Surface Interactions}

The discrepancy between the expected (based on the Ag content) and measured (equilibrium results) $\mathrm{I}^{-}$content and the XPS I3d $\mathrm{d}_{5 / 2}$ peak location could be explained by the formation and adsorption of $\mathrm{I}_{2}$ on the surface of zeolites. Mao et al. observed the same discrepancies on $\mathrm{I}^{-}$content when working with $\mathrm{Ag} @ \mathrm{CuO}_{2}$ nanoparticles [48]. They found that besides the formation of AgI the oxidation of $\mathrm{I}^{-}$to $\mathrm{I}_{2}$ takes place in the presence of $\mathrm{O}_{2}$ in the solution followed by adsorption of $\mathrm{I}_{2}$ on the surface of the nanoparticles. XPS analysis showed that the $\mathrm{I}^{3} \mathrm{~d}_{5 / 2}$ peak can be divided into four different peaks at 618.4, 618.9, 619.4 and $619.7 \mathrm{eV}$, attributed to the peaks of $\mathrm{NaI}, \mathrm{CuI}, \mathrm{AgI}$, and $\mathrm{I}_{2}$, the later having significantly smaller area indicating a small amount of $\mathrm{I}_{2}$. Li et al. also identified a small fraction of $\mathrm{I}_{2}$ species residing at $620.3 \mathrm{eV}$ oxidized by dissolved $\mathrm{O}_{2}$ [72]. These studies are not clear on the possibility of $\mathrm{I}_{2}$ formation in the solution but given the low $\mathrm{I}^{-}$concentration used, the slightly acidic $\mathrm{pH}$ and in the absence of strong oxidant the formation of significant amounts of $\mathrm{I}_{2}$ in the solution is unlikely. Also, it is not clear why the oxidation of $\mathrm{I}_{2}$ by $\mathrm{O}_{2}$ happens only on the surface of the particles. Similar results were presented by Liu et al., however they used $\mathrm{Ag}_{2} \mathrm{O}-\mathrm{Ag} / \mathrm{TiO}_{2}$ materials under visible light irradiation [73]. They found that $\mathrm{I}^{-}$is photocatalytically oxidized to $\mathrm{I}_{2}$ and then it is adsorbed on $\mathrm{AgI}$ to form $\mathrm{AgI}_{3}$ and $\mathrm{AgI}_{2 \mathrm{n}+1}$ complexes and, as a result, only $\mathrm{I}^{-}$attributed to $\mathrm{AgI}$ was detected by XPS. The formation of $\mathrm{AgI}_{3}$ is discussed by Chen et al. who used $\mathrm{Ag}_{2} \mathrm{O}-\mathrm{Ag}_{2} \mathrm{O}_{3}$ ZIF-8 composite but the oxidation of $\mathrm{I}^{-}$is caused by the reduction of $\mathrm{Ag}^{3+}$ to $\mathrm{Ag}^{+}$and the formation of $\mathrm{AgI}$ [16]. Rehakova et al. studied the modification of clinoptilolite with iodide by using concentrated KI solutions and XPS showed two peaks at $\mathrm{I}_{3 / 2} 619.3 \mathrm{eV}$ and $621.1 \mathrm{eV}$ attributed to $\mathrm{I}^{-}$and $\mathrm{I}_{2}$, with $\mathrm{I}^{-} / \mathrm{I}_{2}$ ratio of $3.9[45,46]$. 
According to the authors, the oxidation is happening on the surface due to a redox reaction with the $\mathrm{Fe}^{3+}$ of the zeolite and the produced $\mathrm{I}_{2}$ is adsorbed. A study conducted in the framework of the present study by using Medusa software showed that the aqueous phase speciation of iodide solutions in a mild oxidative environment of $0.6 \mathrm{~V}$ and in acidic to neutral solutions at $0.001 \mathrm{~mol} / \mathrm{L}$ only $\mathrm{I}^{-}$exists, at $0.01 \mathrm{~mol} / \mathrm{L}$ a small amount of about $5 \% \mathrm{I}_{3}{ }^{-}$is formed, at $0.1 \mathrm{~mol} / \mathrm{L}$ the solution contains almost $50 \% \mathrm{I}_{3}{ }^{-}$and at $1 \mathrm{~mol} / \mathrm{L}$ almost $24 \% \mathrm{I}_{3}{ }^{-}$and $68 \%$ of crystalline $\mathrm{I}_{2}$ coexist. Thus, taking into account that, in the presence of iodide and triiodide, iodine is formed [74] in concentrated iodide solutions, the formation of $\mathrm{I}_{2}$ is plausible even without the redox reaction with $\mathrm{Fe}^{3+}$.

The results of the present study show that iodide is not removed by NZU and UV-Vis scans of the blank and other solutions showed no other species than $\mathrm{I}^{-}$. Thus, the dissolved $\mathrm{O}_{2}$ and $\mathrm{Fe}^{3+}$ induced oxidation of $\mathrm{I}^{-}$on the surface of the zeolite can be excluded. Another possibility is the redox reaction between $\mathrm{I}^{-}$and $\mathrm{Ag}_{2} \mathrm{O}$ leading to $\mathrm{I}_{2}$ and $\mathrm{Ag}^{0}$, however such a reaction has not been observed in other studies and there is no strong evidence of this reduction in XRD results (Figure 11). Also, the reduction of $\mathrm{Ag}_{2} \mathrm{O}$ to $\mathrm{Ag}^{0}$ should be hindered by the presence of $\mathrm{I}^{-}$and the formation of AgI. Indeed, regardless the formation of $\mathrm{I}_{2}$ or other products, the formation of AgI in aqueous solutions when iodide interacts with silver has been confirmed in several studies and different materials $[4,5,14,15,33,35,75-78]$ including clinoptilolite $[26,28,29]$. Also, the interaction of $\mathrm{Ag}$ and $\mathrm{I}_{2}$ in aqueous solutions results in the formation of AgI as well [79]. The interaction of iodine with silver has been extensively studied in vapor-solid adsorption and can be a complex phenomenon leading to $\mathrm{I}_{2}$ adsorption and several charged AgI forms [80,81]. Moreover, in the occasion of significant amounts of $I_{2}$, XPS should have detected two peaks at $\mathrm{I}_{3} \mathrm{~d}_{5 / 2}$ indicating the coexistence of both oxidation states of iodide. Although unlikely, in the occasion of $\mathrm{I}^{-}$reduction to $\mathrm{I}_{2}$ on the surface of the zeolite the following reaction can take place [16]:

$$
\mathrm{AgI}+\mathrm{I}_{2} \rightarrow \mathrm{AgI}_{3}
$$

The $\mathrm{AgI}_{3}$ gives a single environment (presumably $\mathrm{I}^{-}$) peak on XPS [16]. Without excluding a contribution from the adsorbed $\mathrm{I}_{2}$ or the formation $\mathrm{AgI}_{3}$, the hypothesis in the present work is that the discrepancy between the expected (XRF) and measured (equilibrium) $\mathrm{I}^{-}$content can be explained by the formation of AgI colloids in the solution and on the surface of the zeolites. The Ag leaching experiments showed that the addition of oxidant results in an increase of silver concentration in the solutions, indicating the existence of some external precipitation of AgI. Nevertheless, of the 52 experiments, only four showed silver concentration higher than 10 ppm and most of measurements were around the average of $5 \mathrm{ppm}$ (Figure 12). The average concentration of Ag the solutions corresponds to about $0.75 \mathrm{mg}$ of leached Ag per gram of zeolite or less than $0.8 \%$ and $1.5 \%$ of the $\mathrm{Ag}$ content of the $\mathrm{Ag}_{2} \mathrm{O} @ \mathrm{NZU}$ and $\mathrm{Ag}^{0} @ \mathrm{NZU}$, respectively.

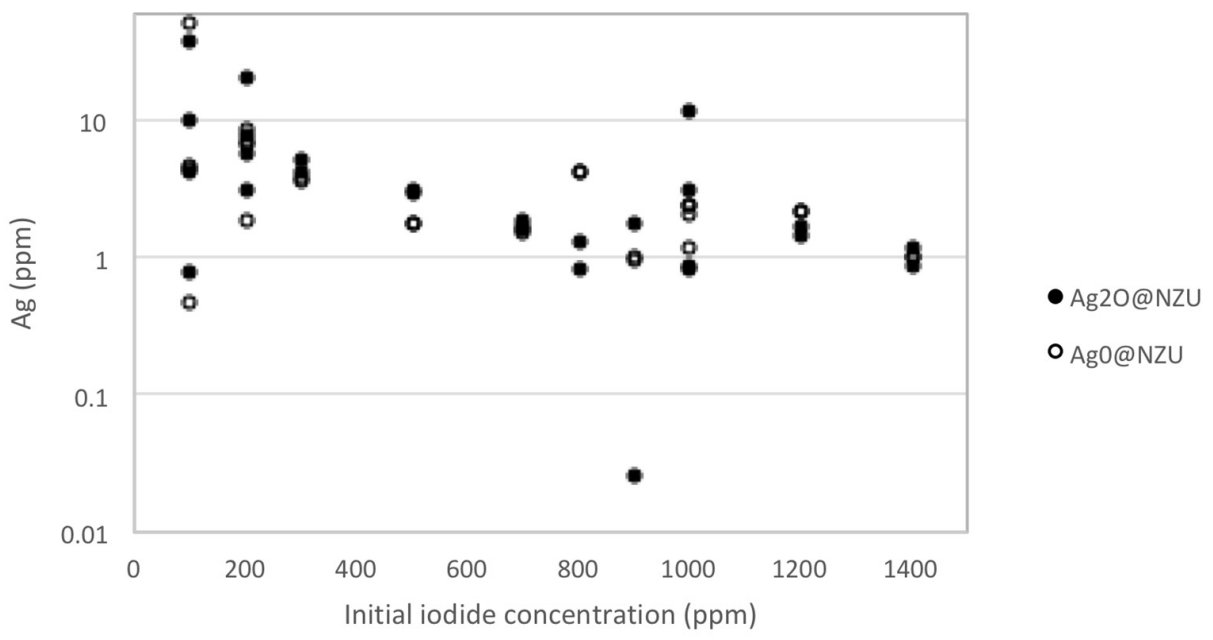

Figure 12. Ag leaching results (52 experiments). 
As Baimenov et al. discussed, when silver ions are released in a solution of excess of iodine ions negatively charged AgI colloids are formed which exhibit Ag:I molar ratios lower than 1 [33]. Indeed, after the iodide adsorption the color of some solutions turned light yellow and UV-Vis scans showed a peak at around $424-427 \mathrm{~nm}$, which is attributed to AgI colloids (Figure 13). The formation of AgI colloids and appearance of the UV-Vis peak at 424-427 nm was not systematic, i.e., depends on time and concentration, and is more likely in higher iodide concentrations. Also, as is clear from the NZU UV-Vis scan, no other peaks than iodide were observed (Figure 13). However, the leached amount of silver does not seem enough to account for the excess of iodide removed from the solution thus we postulate the formation of negatively charged AgI colloids or Ag-I complexes on the surface of the zeolites. Also, the formation of colloids and/or complexes can explain the removal of $\mathrm{K}^{+}$from the solution it can be adsorbed on the negatively charged Ag-I complexes or AgI colloids to form the Stern layer. Notably, other studies have shown that the otherwise insoluble AgI can be partly emulsified into small clusters if sufficient excess iodide ions are present $[82,83]$. These clusters contain AgI pairs and excess of iodide ions and are surrounded by an electrolyte solution rather than being part of a lattice [83]. The deposition of colloids from the water on solids surfaces is a well-known phenomenon [84], but further analysis on the deposition or formation of colloids on the surface of solids is beyond the scope of the present study.

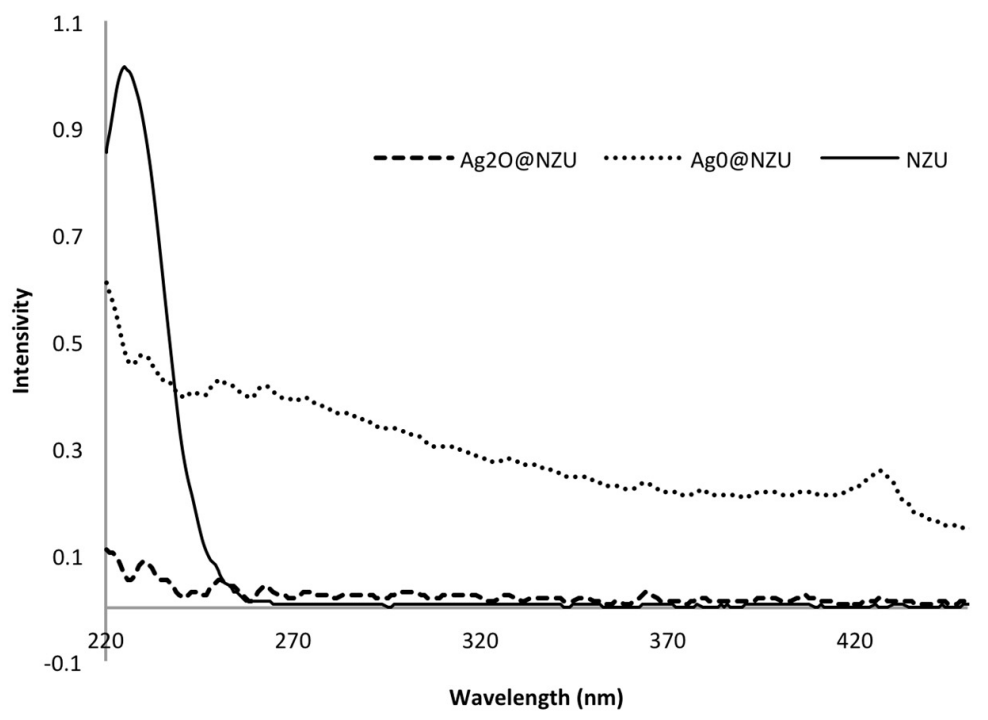

Figure 13. UV-Vis scan after $72 \mathrm{~h}$ of adsorption at $200 \mathrm{ppm}$ iodide.

The differences between the $\mathrm{Ag}_{2} \mathrm{O} @ \mathrm{NZU}$ and $\mathrm{Ag}^{0} @ \mathrm{NZU}$ samples in terms of removal rate and maximum capacity can be explained by the difference in Ag content. However, another decisive factor is the reaction mechanism, which favors the $\mathrm{Ag}_{2} \mathrm{O} @ \mathrm{NZU}$ sample. The reactions are as follows [33]:

$$
\begin{gathered}
4 \mathrm{Ag}^{0}+\mathrm{O}_{2} \rightarrow 2 \mathrm{Ag}_{2} \mathrm{O} \\
\mathrm{Ag}_{2} \mathrm{O}+2 \mathrm{H}^{+} \rightarrow 2 \mathrm{Ag}^{+}+\mathrm{H}_{2} \mathrm{O} \\
\mathrm{Ag}^{+}+\mathrm{I}^{-} \rightarrow \mathrm{AgI} \\
\mathrm{Ag}^{+}+\mathrm{nI}^{-}+\mathrm{mK}^{+} \rightarrow\left[\left(\mathrm{AgI}_{\mathrm{n}}\right)^{1-n} \mathrm{~K}^{m}\right]^{(m+1)-n}
\end{gathered}
$$

The precipitation reaction $\mathrm{R} 5$ requires $\mathrm{Ag}^{+}$and thus $\mathrm{Ag}^{0}$ has to be oxidized first following reactions R3 and R4. This will impede the removal of iodide by $\mathrm{Ag}^{0} @ \mathrm{NZU}$ resulting in slower kinetics and, if oxidation is incomplete, to lower capacity, explaining the kinetics (Figure 4) and equilibrium results (Figure 5). As the reaction proceeds, an $\mathrm{AgI}$ layer forms below the $\mathrm{Ag}_{2} \mathrm{O}$ layer through which oxygen and iodide involved in the reaction diffuse. The mechanism was described by Krausmann 
and Drossinos, who used bulk silver $(2 \mu \mathrm{m})$ to react with iodide and iodine in aqueous solutions [79]. In addition, they argued that the AgI layer is non-porous, since the molar volume of the iodide is greater than metallic silver by a factor of 2.5. This means that the size of Ag nanoparticles affects the overall removal rate. The proposed mechanism can possibly explain the Langmuir isotherm for $\mathrm{Ag}^{0} @ \mathrm{NZU}$ as the overall removal depends on three rather one reaction. Also, the pH of the solutions was increased from about 6 for KI to about 7.6 for $\mathrm{Ag}_{2} \mathrm{O} @ \mathrm{NZU}$ and almost 10.4 for $\mathrm{Ag}^{0} @ \mathrm{NZU}$. Reaction $\mathrm{R} 4$ can explain the increase of $\mathrm{pH}$ but in the case of $\mathrm{Ag}^{0} @ \mathrm{NZU}$ there is no obvious reason for such a considerable $\mathrm{pH}$ increase and more experiments are needed to study this effect. Finally, reaction R6 leads to the formation of colloids in the solution and on the surface of the zeolites providing a reasonable explanation of the excess iodide found in equilibrium experiments and the $\mathrm{K}^{+}$removal from the solution. Also, as the $\mathrm{I}^{-}$is loosely bounded on these complexes and colloids they can be easier lost under high-energy radiation, especially when characterizations are done in vacuum as is the case of XRF, SEM/EDS and TEM/EDS.

To further illustrate the effect of silver form on the removal mechanism, mercury removal experiments were conducted and the results showed a reverse in the achieved capacities in comparison to iodide removal. In particular, the maximum loading for $\mathrm{Ag}^{0} @ \mathrm{NZU}$ was about $29 \mathrm{mg} / \mathrm{g}$ almost double than this of $\mathrm{Ag}_{2} \mathrm{O} @ \mathrm{NZU}$, which was about $14 \mathrm{mg} / \mathrm{g}$. Reactions R3 and R4 take place along with the following [85]:

$$
\begin{aligned}
\mathrm{Ag}^{0}+\mathrm{Hg}^{2+} & \rightarrow \mathrm{Ag}^{+}+\mathrm{Hg}^{+} \\
\mathrm{Ag}^{+}+\mathrm{Cl}^{-} & \rightarrow \mathrm{AgCl} \\
2 \mathrm{Hg}^{+}+2 \mathrm{Cl}^{-} & \rightarrow \mathrm{Hg}_{2} \mathrm{Cl}_{2}
\end{aligned}
$$

Reaction $\mathrm{R} 7$ requires the presence of $\mathrm{Ag}^{0}$ and this is the reason of the higher mercury removal by $\mathrm{Ag}^{0} @ \mathrm{NZU}$. Also, $\mathrm{Ag}_{2} \mathrm{O} @ \mathrm{NZU}$ sample removes some mercury owing to some $\mathrm{Ag}^{0}$ in its structure as XPS analysis showed (Table 6 and Figure 11). Thus, it is the silver content combined to the reaction mechanism that can favor one silver form over another. Nevertheless, more experiments are needed in order to better understand the interplay between aqueous and solid phase chemistry.

\section{Conclusions}

A natural zeolite with $80 \%$ clinoptilolite content was modified with silver following two different methods. XRD, XRF, XPS, and TEM characterizations showed that the derived zeolites are decorated with $\mathrm{Ag}_{2} \mathrm{O}$ and $\mathrm{Ag}^{0}$ nanoparticles of size of $5-25 \mathrm{~nm}$ and the silver content is between $55 \mathrm{and} 89 \mathrm{mg} / \mathrm{g}$. The materials were used for the removal of iodide from aqueous solutions in a wide range of initial concentrations, i.e., from 30 to 1400 ppm. While the natural zeolite shows no affinity for iodide, silver forms can remove up to $132 \mathrm{mg} / \mathrm{g}$ iodide. The study of the removal mechanism is challenging and the kinetics and equilibrium results along with XRD, XRF, SEM/EDS, XPS, and TEM/EDS characterizations were used to interpret the phenomena that take place on the surface of the zeolites. The experimental data showed that AgI precipitate, AgI colloids, and Ag-I complexes are formed in the solutions and possibly on the surface of the materials. Based on these observations, a set of probable reactions is provided.

Author Contributions: Conceptualization, V.J.I.; methodology, V.J.I.; software, A.Y. and J.F.-P.; validation, V.J.I., J.C.B. and K.M.; formal analysis, V.J.I.; investigation, A.S. and A.Y.; resources, V.J.I and J.F.-P.; data curation, Z.T. and K.M.; writing — original draft preparation, V.J.I.; writing—review and editing, V.J.I. and J.C.B.; visualization, V.J.I. and J.C.B.; supervision, V.J.I.; project administration, V.J.I.; funding acquisition, V.J.I. All authors have read and agreed to the published version of the manuscript.

Funding: This research was funded by the Nazarbayev University under the project entitled "Noble metals nanocomposites hyper-activity in heterogeneous non-catalytic and catalytic reactions", Grant No. 110119FD4536 and by the European Commission HORIZON 2020 project "Nanoporous and Nanostructured Materials for Medical Applications (NanoMed)"', H2020-MSCA-RISE-2016, 734641.

Acknowledgments: The authors acknowledge the support by Kingston University c/o GCRF grant number P2034-106. 
Conflicts of Interest: The authors declare no conflict of interest.

\section{References}

1. Jang, J.; Lee, D.S. Magnetite nanoparticles supported on organically modified montmorillonite for adsorptive removal of iodide from aqueous solution: Optimization using response surface methodology. Sci. Total Environ. 2018, 615, 549-557. [CrossRef] [PubMed]

2. Mao, P.; Qi, L.; Liu, X.; Liu, Y.; Jiao, Y.; Chen, S.; Yang, Y. Synthesis of Cu/Cu2O hydrides for enhanced removal of iodide from water. J. Hazard. Mater. 2017, 328, 21-28. [CrossRef] [PubMed]

3. Huve, J.; Ryzhikov, A.; Nouali, H.; Lalia, V.; Augé, G.; Daou, T.J. Porous sorbents for the capture of radioactive iodine compounds: A review. RSC Adv. 2018, 8, 29248-29273. [CrossRef]

4. Mao, P.; Liu, Y.; Liu, X.; Wang, Y.; Liang, J.; Zhou, Q.; Dai, Y.; Jiao, Y.; Chen, S.; Yang, Y. Bimetallic $\mathrm{AgCu} / \mathrm{Cu}_{2} \mathrm{O}$ hybrid for the synergetic adsorption of iodide from solution. Chemosphere 2017, 180, 317-325. [CrossRef] [PubMed]

5. Tauanov, Z.; Inglezakis, V.J. Removal of iodide from water using silver nanoparticles-impregnated synthetic zeolites. Sci. Total Environ. 2019, 682, 259-270. [CrossRef]

6. Yoshida, S.; Ojino, M.; Ozaki, T.; Hatanaka, T.; Nomura, K.; Ishii, M.; Koriyama, K.; Akashi, M. Guidelines for iodine prophylaxis as a protective measure: Information for physicians. Japan Med. Assoc. J. 2014, 57, 113-123.

7. Kireev, S.V.; Shnyrev, S.L. Study of molecular iodine, iodate ions, iodide ions, and triiodide ions solutions absorption in the UV and visible light spectral bands. Laser Phys. 2015, 25, 75602. [CrossRef]

8. Xing, C.; Yang, G.; Lu, P.; Shen, W.; Gai, X.; Tan, L.; Mao, J.; Wang, T.; Yang, R.; Tsubaki, N. A hierarchically spherical Co-based zeolite catalyst with aggregated nanorods structure for improved Fischer-Tropsch synthesis reaction activity and isoparaffin selectivity. Microporous Mesoporous Mater. 2016, 233, $62-69$. [CrossRef]

9. Andersen, S.; Guan, H.; Teng, W.; Laurberg, P. Speciation of iodine in high iodine groundwater in China associated with goitre and hypothyroidism. Biol. Trace Elem. Res. 2009, 128, 95-103. [CrossRef] [PubMed]

10. Georgiev, G.L.; Trzebicka, B.; Kostova, B.; Petrov, P.D. Super-macroporous dextran cryogels via UV-induced crosslinking: Synthesis and characterization. Polym. Int. 2017, 66, 1306-1311. [CrossRef]

11. Zhao, J.; Chen, Z.; Maberly, G. Iodine-rich drinking water of natural origin in China. Lancet 1998, $352,2024$. [CrossRef]

12. Hamasaki, T.; Nakamichi, N.; Teruya, K.; Shirahata, S. Removal efficiency of radioactive cesium and iodine ions by a flow-type apparatus designed for electrochemically reduced water production. PLoS ONE 2014, 9, e102218. [CrossRef] [PubMed]

13. Inoue, H.; Kagoshima, M.; Yamasaki, M.; Honda, Y. Radioactive iodine waste treatment using electrodialysis with an anion exchange paper membrane. Appl. Radiat. Isot. 2004, 61, 1189-1193. [CrossRef] [PubMed]

14. Chen, Y.Y.; Yu, S.H.; Yao, Q.Z.; Fu, S.Q.; Zhou, G.T. One-step synthesis of Ag2O@Mg(OH)2 nanocomposite as an efficient scavenger for iodine and uranium. J. Colloid Interface Sci. 2018, 510, 280-291. [CrossRef] [PubMed]

15. Sánchez-Polo, M.; Rivera-Utrilla, J.; Salhi, E.; von Gunten, U. Ag-doped carbon aerogels for removing halide ions in water treatment. Water Res. 2007, 41, 1031-1037. [CrossRef] [PubMed]

16. Chen, J.; Gao, Q.; Zhang, X.; Liu, Y.; Wang, P.; Jiao, Y.; Yang, Y. Nanometer mixed-valence silver oxide enhancing adsorption of ZIF-8 for removal of iodide in solution. Sci. Total Environ. 2019, 646, 634-644. [CrossRef] [PubMed]

17. Asmussen, R.M.; Neeway, J.J.; Lawter, A.R.; Wilson, A.; Qafoku, N.P. Silver-based getters for 129I removal from low-activity waste. Radiochim. Acta 2016, 104, 905-913. [CrossRef]

18. Yu, F.; Chen, Y.; Wang, Y.; Liu, C.; Ma, W. Enhanced removal of iodide from aqueous solution by ozonation and subsequent adsorption on Ag-Ag2O modified on Carbon Spheres. Appl. Surf. Sci. 2018, 427, 753-762. [CrossRef]

19. Golubeva, O.Y.; Ul'yanova, N.Y. Stabilization of silver nanoparticles and clusters in porous zeolite matrices with Rho, Beta, and paulingite structures. Glas. Phys. Chem. 2015, 41, 537-544. [CrossRef]

20. Inglezakis, V.J.; Loizidou, M.D.; Grigoropoulou, H.P. Equilibrium and kinetic ion exchange studies of $\mathrm{Pb} 2+$, $\mathrm{Cr} 3+, \mathrm{Fe} 3+$ and $\mathrm{Cu} 2+$ on natural clinoptilolite. Water Res. 2002, 36, 2784-2792. [CrossRef] 
21. Kuntubek, A.; Kinayat, N.; Meiramkulova, K.; Poulopoulos, S.; Bear, J.C.; Inglezakis, V.J. Catalytic Oxidation of Methylene Blue by Use of Natural Zeolite-Based Silver and Magnetite Nanocomposites. Processes 2020, 8 , 471. [CrossRef]

22. Loganathan, P.; Vigneswaran, S.; Kandasamy, J.; Naidu, R. Defluoridation of drinking water using adsorption processes. J. Hazard. Mater. 2013, 248-249, 1-19. [CrossRef] [PubMed]

23. Chebbi, M.; Azambre, B.; Cantrel, L.; Huvé, M.; Albiol, T. Influence of structural, textural and chemical parameters of silver zeolites on the retention of methyl iodide. Microporous Mesoporous Mater. 2017, 244, 137-150. [CrossRef]

24. Warchoł, J.; Misaelides, P.; Petrus, R.; Zamboulis, D. Preparation and application of organo-modified zeolitic material in the removal of chromates and iodides. J. Hazard. Mater. 2006, 137, 1410-1416. [CrossRef] [PubMed]

25. Faghihian, H.; Malekpour, A.; Maragheh, M.G. Removal of radioactive iodide by surfactant-modified zeolites. Adsorpt. Sci. Technol. 2003, 21, 373-381. [CrossRef]

26. Chmielewská-Horváthová, E.; Lesný, J. Iodide adsorption on the surface of chemically pretreated clinoptilolite. J. Radioanal. Nucl. Chem. Lett. 1995, 200, 351-363. [CrossRef]

27. Han, S.; Um, W.; Kim, W.S. Development of bismuth-functionalized graphene oxide to remove radioactive iodine. Dalt. Trans. 2019, 48, 478-485. [CrossRef] [PubMed]

28. Faghihian, H.; Maragheh, M.G.; Malekpour, A. Adsorption of radioactive iodide by natural zeolites. J. Radioanal. Nucl. Chem. 2002, 254, 545-550. [CrossRef]

29. Gradev, G.D. Sorption of iodide ions on cationic forms of clinoptilolite. J. Radioanal. Nucl. Chem. Artic. 1987, 116, 341-346. [CrossRef]

30. Park, S.; An, H.; Park, M.B.; Lee, J. Adsorption behavior of methyl iodide on a silver ion-exchanged ZSM-5. Microporous Mesoporous Mater. 2020, 294, 109842. [CrossRef]

31. Azambre, B.; Chebbi, M.; Hijazi, A. Effects of the cation and Si/Al ratio on CH3I adsorption by faujasite zeolites. Chem. Eng. J. 2020, 379, 122308. [CrossRef]

32. Chapman, K.W.; Chupas, P.J.; Nenoff, T.M. Radioactive iodine capture in silver-containing mordenites through nanoscale silver iodide formation. J. Am. Chem. Soc. 2010, 132, 8897-8899. [CrossRef] [PubMed]

33. Baimenov, A.Z.; Berillo, D.A.; Inglezakis, V.J. Cryogel-based $\mathrm{Ag}^{\circ} / \mathrm{Ag} 2 \mathrm{O}$ nanocomposites for iodide removal from water. J. Mol. Liq. 2019, 299, 112134. [CrossRef]

34. Lihareva, N.; Dimova, L.; Petrov, O.; Tzvetanova, Y. Ag+ sorption on natural and Na-exchanged clinoptilolite from Eastern Rhodopes, Bulgaria. Microporous Mesoporous Mater. 2010, 130, 32-37. [CrossRef]

35. Bo, A.; Sarina, S.; Zheng, Z.; Yang, D.; Liu, H.; Zhu, H. Removal of radioactive iodine from water using Ag2O grafted titanate nanolamina as efficient adsorbent. J. Hazard. Mater. 2013, 246-247, 199-205. [CrossRef] [PubMed]

36. Tauanov, Z.; Tsakiridis, P.E.; Shah, D.; Inglezakis, V.J. Synthetic sodalite doped with silver nanoparticles: Characterization and mercury (II) removal from aqueous solutions. J. Environ. Sci. Heal. Part A Toxic/Hazardous Subst. Environ. Eng. 2019, 54, 951-959. [CrossRef] [PubMed]

37. Tauanov, Z.; Tsakiridis, P.E.; Mikhalovsky, S.V.; Inglezakis, V.J. Synthetic coal fly ash-derived zeolites doped with silver nanoparticles for mercury (II) removal from water. J. Environ. Manage. 2018, 224, 164-171. [CrossRef] [PubMed]

38. Mulfinger, L.; Solomon, S.D.; Bahadory, M.; Jeyarajasingam, A.V.; Rutkowsky, S.A.; Boritz, C. Synthesis and Study of Silver Nanoparticles. J. Chem. Educ. 2007, 84, 322. [CrossRef]

39. Kassim, I.A.R.; Moloney, G.; Busili, A.; Nur, A.Y.; Paron, P.; Jooste, P.; Gadain, H.; Seal, A.J. Iodine Intake in Somalia Is Excessive and Associated with the Source of Household Drinking Water. J. Nutr. 2014, 144, 375-381. [CrossRef] [PubMed]

40. Henjum, S.; Barikmo, I.; Gjerlaug, A.K.; Mohamed-Lehabib, A.; Oshaug, A.; Arne Strand, T.; Torheim, L.E. Endemic goitre and excessive iodine in urine and drinking water among Saharawi refugee children. Proc. Public Health Nutr. 2010, 13, 1472-1477.

41. Moritz, M.; Geszke-Moritz, M. The newest achievements in synthesis, immobilization and practical applications of antibacterial nanoparticles. Chem. Eng. J. 2013, 228, 596-613. [CrossRef]

42. Stylianou, M.; Inglezakis, V.; Agapiou, A.; Itskos, G.; Jetybayeva, A.; Loizidou, M. A comparative study on phyllosilicate and tectosillicate mineral structural properties. Desalin. Water Treat. 2018, 112, 119-146. [CrossRef] 
43. Tarach, K.; Góra-Marek, K.; Chrzan, M.; Walas, S. Quantification of silver sites in zeolites: Carbon monoxide sorption monitored by IR spectroscopy. J. Phys. Chem. C 2014, 118, 23751-23760. [CrossRef]

44. Kubota, T.; Fukutani, S.; Ohta, T.; Mahara, Y. Removal of radioactive cesium, strontium, and iodine from natural waters using bentonite, zeolite, and activated carbon. J. Radioanal. Nucl. Chem. 2013, 296, 981-984. [CrossRef]

45. Reháková, M.; Sopková, A.; Casciola, M.; Bastl, Z. Ac and dc conductivity study of natural zeolitic material of the clinoptilolite type and its iodine forms. Solid State Ionics 1993, 66, 189-194. [CrossRef]

46. Reháková, M.; Sopková, A.; Lokaj, J. Natural zeolitic material of the clinoptilolite type doped with iodine and its ions. J. Incl. Phenom. Mol. Recognit. Chem. 1992, 14, 47-54. [CrossRef]

47. Burgess, A.E.; Davidson, J.C. A kinetic-equilibrium study of a triiodide concentration maximum formed by the persulfate-iodide reaction. J. Chem. Educ. 2012, 89, 814-816. [CrossRef]

48. Mao, P.; Liu, Y.; Jiao, Y.; Chen, S.; Yang, Y. Enhanced uptake of iodide on Ag@Cu2O nanoparticles. Chemosphere 2016, 164, 396-403. [CrossRef]

49. Li, H.; Li, Y.; Li, B.; Liu, D.; Zhou, Y. Highly selective anchoring silver nanoclusters on MOF/SOF heterostructured framework for efficient adsorption of radioactive iodine from aqueous solution. Chemosphere 2020, 252, 126448. [CrossRef] [PubMed]

50. Mao, P.; Qi, B.; Liu, Y.; Zhao, L.; Jiao, Y.; Zhang, Y.; Jiang, Z.; Li, Q.; Wang, J.; Chen, S.; et al. AgII doped MIL-101 and its adsorption of iodine with high speed in solution. J. Solid State Chem. 2016, 237, $274-283$. [CrossRef]

51. Zhao, X.; Han, X.; Li, Z.; Huang, H.; Liu, D.; Zhong, C. Enhanced removal of iodide from water induced by a metal-incorporated porous metal-organic framework. Appl. Surf. Sci. 2015, 351, 760-764. [CrossRef]

52. Lauridsen, J.; Eklund, P.; Lu, J.; Knutsson, A.; Odén, M.; Mannerbro, R.; Andersson, A.M.; Hultman, L. Microstructural and chemical analysis of AgI coatings used as a solid lubricant in electrical sliding contacts. Tribol. Lett. 2012, 46, 187-193. [CrossRef]

53. Malm, J.O.; Schmid, G.; Morun, B. A high-resolution electron microscopy study of silver particles and surfaces. Philos. Mag. A Phys. Condens. Matter Struct. Defects Mech. Prop. 1991, 63, 487-502. [CrossRef]

54. Ng, C.H.B.; Fan, W.Y. Controlled synthesis of $\beta$-AgI nanoplatelets from selective nucleation of twinned Ag seeds in a tandem reaction. J. Phys. Chem. C 2007, 111, 2953-2958. [CrossRef]

55. NIST NIST X-ray Photoelectron Spectroscopy Database, NIST Standard Reference Database 20, Version 4.1.

56. Zhai, Q.Z.; Qiu, S.; Xiao, F.S.; Zhang, Z.T.; Shao, C.L.; Han, Y. Preparation, characterization, and optical properties of the host-guest nanocomposite material zeolite-silver iodide. Mater. Res. Bull. 2000, 35, 59-73. [CrossRef]

57. Bashouti, M.Y.; Talebi, R.; Kassar, T.; Nahal, A.; Ristein, J.; Unruh, T.; Christiansen, S.H. Systematic Surface Phase Transition of Ag Thin Films by Iodine Functionalization at Room Temperature: Evolution of Optoelectronic and Texture Properties. Sci. Rep. 2016, 6, 1-9. [CrossRef] [PubMed]

58. Bastl, Z.; Gehlmann, H. X-ray photoelectron spectroscopic (XPS) studies of iodine oxocompounds. Collect. Czechoslov. Chem. Commun. 1988, 53, 425-432. [CrossRef]

59. Taucher, T.C.; Hehn, I.; Hofmann, O.T.; Zharnikov, M.; Zojer, E. Understanding Chemical versus Electrostatic Shifts in X-ray Photoelectron Spectra of Organic Self-Assembled Monolayers. J. Phys. Chem. C 2016, 120, 3428-3437. [CrossRef] [PubMed]

60. Sarasola, A.; Abadía, M.; Rogero, C.; Garcia-Lekue, A. Theoretical Insights into Unexpected Molecular Core Level Shifts: Chemical and Surface Effects. J. Phys. Chem. Lett. 2017, 8, 5718-5724. [CrossRef] [PubMed]

61. Jacquemin, M.; Genet, M.J.; Gaigneaux, E.M.; Debecker, D.P. Calibration of the X-ray photoelectron spectroscopy binding energy scale for the characterization of heterogeneous catalysts: Is everything really under control? ChemPhysChem 2013, 14, 3618-3626. [CrossRef] [PubMed]

62. Zojer, E.; Taucher, T.C.; Hofmann, O.T. The Impact of Dipolar Layers on the Electronic Properties of Organic/Inorganic Hybrid Interfaces. Adv. Mater. Interfaces 2019, 6, 6. [CrossRef]

63. Greczynski, G.; Hultman, L. X-ray photoelectron spectroscopy: Towards reliable binding energy referencing. Prog. Mater. Sci. 2020, 107, 100591. [CrossRef]

64. Grünert, W.; Schlogl, R. Photoelectron Spectroscopy of Zeolites. Mol. Sieves 2004, 4, 467-515.

65. Günter, T.; Casapu, M.; Doronkin, D.; Mangold, S.; Trouillet, V.; Augenstein, T.; Grunwaldt, J.D. Potential and limitations of natural chabazite for selective catalytic reduction of NOx with NH3. Chemie-Ingenieur-Technik 2013, 85, 632-641. [CrossRef] 
66. Ruiz-Serrano, D.; Flores-Acosta, M.; Conde-Barajas, E.; Ramírez-Rosales, D.; Yáñez-Limón, J.M.; Ramírez-Bon, R. Study by XPS of different conditioning processes to improve the cation exchange in clinoptilolite. J. Mol. Struct. 2010, 980, 149-155. [CrossRef]

67. Chmielewská, E.; Tylus, W.; Drábik, M.; Majzlan, J.; Kravčak, J.; Williams, C.; Čaplovičová, M. Čaplovič Structure investigation of nano- $\mathrm{FeO}(\mathrm{OH})$ modified clinoptilolite tuff for antimony removal. Microporous Mesoporous Mater. 2017, 248, 222-233. [CrossRef]

68. Panayotova, M.I.; Mintcheva, N.N.; Gemishev, O.T.; Tyuliev, G.T.; Gicheva, G.D.; Djerahov, L.P. Preparation and antimicrobial properties of silver nanoparticles supported by natural zeolite clinoptilolite. Bulg. Chem. Commun. 2018, 50, 211-218.

69. Borkó, L.; Nagy, I.; Schay, Z.; Guczi, L. Low and high activity states in the oxidation of m-xylene on palladium catalysts. Appl. Catal. A Gen. 1996, 147, 95-108. [CrossRef]

70. Wei, Y.X.; Ye, Z.F.; Wang, Y.L.; Ma, M.G.; Li, Y.F. Enhanced ammonia nitrogen removal using consistent ammonium exchange of modified zeolite and biological regeneration in a sequencing batch reactor process. Environ. Technol. 2011, 32, 1337-1343. [CrossRef] [PubMed]

71. Greczynski, G.; Hultman, L. Compromising Science by Ignorant Instrument Calibration-Need to Revisit Half a Century of Published XPS Data. Angew. Chemie Int. Ed. 2020, 59, 5002-5006. [CrossRef] [PubMed]

72. Li, J.; Wang, M.; Liu, G.; Zhang, L.; He, Y.; Xing, X.; Qian, Z.; Zheng, J.; Xu, C. Enhanced Iodide Removal from Water by Nano-Silver Modified Anion Exchanger. Ind. Eng. Chem. Res. 2018, 57, 17401-17408. [CrossRef]

73. Liu, S.; Wang, N.; Zhang, Y.; Li, Y.; Han, Z.; Na, P. Efficient removal of radioactive iodide ions from water by three-dimensional $\mathrm{Ag} 2 \mathrm{O}-\mathrm{Ag} / \mathrm{TiO} 2$ composites under visible light irradiation. J. Hazard. Mater. 2015, 284, 171-181. [CrossRef] [PubMed]

74. Zhang, X.; Stewart, S.; Shoesmith, D.W.; Wren, J.C. Interaction of Aqueous Iodine Species with $\mathrm{Ag}_{2} \mathrm{O} / \mathrm{Ag}$ Surfaces. J. Electrochem. Soc. 2007, 154, F70. [CrossRef]

75. Buffle, J.; Zhang, Z.; Startchev, K. Metal flux and dynamic speciation at (Bio)interfaces. Part I: Critical evaluation and compilation of physicochemical parameters for complexes with simple ligands and fulvic/humic substances. Environ. Sci. Technol. 2007, 41, 7609-7620. [CrossRef] [PubMed]

76. Sánchez-Polo, M.; Rivera-Utrilla, J.; Salhi, E.; von Gunten, U. Removal of bromide and iodide anions from drinking water by silver-activated carbon aerogels. J. Colloid Interface Sci. 2006, 300, 437-441. [CrossRef] [PubMed]

77. Polo, A.M.; Velo-Gala, I.; Sánchez-Polo, M.; von Gunten, U.; López-Peñalver, J.J.; Rivera-Utrilla, J. Halide removal from aqueous solution by novel silver-polymeric materials. Sci. Total Environ. 2016, 573, 1125-1131.

78. Hoskins, J.S.; Karanfil, T.; Serkiz, S.M. Removal and sequestration of iodide using silver-impregnated activated carbon. Environ. Sci. Technol. 2002, 36, 784-789. [CrossRef] [PubMed]

79. Krausmann, E.; Drossinos, Y. A model of silver \pm iodine reactions in a light water reactor containment sump under severe accident conditions. J. Nucl. Mater. 1999, 264, 113-121. [CrossRef]

80. MATSUOKA, S.; NAKAMURA, H.; TAMURA, T.; Takano, T.; ITO, Y. Stability and Chemical Form of Iodine Sorbed on Silver-Exchanged Zeolite X. J. Nucl. Sci. Technol. 1984, 22, 862-870. [CrossRef]

81. Wu, L.; Sawada, J.A.; Kuznicki, D.B.; Kuznicki, T.; Kuznicki, S.M. Iodine adsorption on silver-exchanged titania-derived adsorbents. J. Radioanal. Nucl. Chem. 2014, 302, 527-532. [CrossRef]

82. Validzic, I.L.; Kegel, W.K. Influence of adsorbing species on properties of equilibrium silver iodide clusters. J. Colloid Interface Sci. 2004, 275, 197-203. [CrossRef] [PubMed]

83. Mladenovic, I.L.; Kegel, W.K.; Bomans, P.; Frederik, P.M. Observation of equilibrium, nanometer-sized clusters of silver iodide in aqueous solutions. J. Phys. Chem. B 2003, 107, 5717-5722. [CrossRef]

84. Chen, K.L.; Smith, B.A.; Ball, W.P.; Fairbrother, D.H. Assessing the colloidal properties of engineered nanoparticles in water: Case studies from fullerene C60 nanoparticles and carbon nanotubes. Environ. Chem. 2010, 7, 10-27. [CrossRef]

85. Tauanov, Z.; Lee, J.; Inglezakis, V.J. Mercury reduction and chemisorption on the surface of synthetic zeolite silver nanocomposites: Equilibrium studies and mechanisms. J. Mol. Liq. 2020, 305, 112825. [CrossRef]

(C) 2020 by the authors. Licensee MDPI, Basel, Switzerland. This article is an open access article distributed under the terms and conditions of the Creative Commons Attribution (CC BY) license (http://creativecommons.org/licenses/by/4.0/). 